\title{
NATURALEZA JURIDICA DEL CONTRATO JOINT VENTURE EN COLOMBIA
}

GREGORIO GUTIÉRREZ TORRES 


\section{CAPÍTULO I}

\section{ASPECTOS GENERALES DEL CONTRATO DE JOINT VENTURE}

\section{INTRODUCCIÓN}

Con el advenimiento de la globalización de los mercados y la producción, la empresa privada se ensanchó, empezó a desarrollar negocios allende las fronteras y surgió la necesidad de asociarse con otras compañías para ampliar su oferta de servicios, ingresar en mercados emergentes, aprovechar la transferencia de tecnología (patentes y know how) de sociedades transnacionales, ejecutar proyectos de infraestructura y obras, disminuir costos y riesgos y, en general, para invertir en los diferentes sectores económicos con mayor competitividad.

La asociación de empresas, más comúnmente conocida en el lenguaje de los negocios internacionales como alianza estratégica o joint venture ${ }^{1}$, es un instrumento jurídico-económico de amplia utilización en la economía global, y sobre la que ya se han expedidos algunas leyes a nivel nacional e internacional.

Sin embargo, en el ordenamiento jurídico interno la figura no está suficientemente regulada, a diferencia de otros contratos y negocios mercantiles como, por ejemplo, el contrato de sociedad, el contrato de fiducia, la compraventa nacional e internacional, el contrato de mutuo o la agencia comercial que sí tienen una regulación expresa en el Código de Comercio (Cfr. GAVIRIA GUTIÉRREZ, 1996, pp. 185 - 188). Indudablemente, la figura jurídica objeto de estudio se ha

\footnotetext{
1 "Joint Venture. Proviene del verbo to join, que significa $\langle<j u n t a r\rangle>,<<l i g a r\rangle>,<<a f i l i a r s e \gg$, $<<$ asociarse〉>. Ahora bien, el sustantivo joint venture equivale en nuestro idioma a unión. Por su parte, venture denota empresa, negocio, negocio arriesgado. Luego es claro su ssignificado: empresa en común. La expresión joint venture deriva de joint adventure, entendiendo por adventure el riesgo o aventura" (PEÑA NOSSA, 2014, pp. 543 -544).
} 
empleado en toda clase de operaciones y actividades mercantiles, no obstante su carácter atípico en la legislación nacional.

La asociación de empresas, también denominada alianza estratégica o joint venture $^{2}$ no es una figura jurídica de reciente aparición en el ámbito contractual y empresarial, sino que, por el contrario, se remonta a la noche de los tiempos, desde que el hombre empezó a asociarse para invertir, desarrollar actividades económicas y obtener utilidades con éstas. Es consustancial al florecimiento de las sociedades comerciales (Cfr. MIQUEL RODRÍGUEZ, 1998, pp. 81 - 92), no obstante que un amplio sector de la doctrina considera que dicha figura jurídica se originó en la Partnership del derecho anglosajón. Pero más allá de los dilemas histórico-jurídicos concernientes al nacimiento de esta figura, lo que aquí nos interesa discutir y analizar es lo tocante a la naturaleza jurídica y a los problemas jurídicos y empresariales que de allí se derivan.

Sea lo primero advertir, que si bien es cierto que en nuestro país la figura jurídica en mención ha sido frecuentemente empleada en proyectos de infraestructura y obras, así como de interés social, telecomunicaciones, inversión minera y petrolera, así como en el sector de los servicios (Cfr. PARRA, 2004, pp. 109 126), la doctrina y la jurisprudencia local no le han prestado toda la atención que se merece, y mucho menos se puede afirmar que existe una doctrina armonizada y uniforme sobre el joint venture y su utilización en el derecho colombiano.

Por ello, el interés en realizar un tratamiento de la figura desde una perspectiva crítica, analítica si se quiere, que permita presentar algunas propuestas y

\footnotetext{
2 "Una joint venture significa establecer una firma que es propiedad colectiva e dos o más firmas independientes (...). Las joint ventures tienen una serie de ventajas. En primer lugar, una firma se beneficia del conocimiento que el socio local tiene sobre las condiciones competitivas, la cultura, el idioma, los sistemas políticos y los sistemas de negocios del país anfitrión. Así, para muchas firmas estadounidenses, las joint ventures han implicado que la compañía estadounidense provea conocimiento tecnológico y productos y que el socio local provea un conocimiento relativo al marketing y el conocimiento local necesarios para competir en ese país" (HILL, 2001, pp. 492 493).
} 
soluciones a la problemática que genera este contrato atípico en la dinámica empresarial y de los negocios del siglo XXI, y habida cuenta de la interacción entre los distintos sistemas jurídicos de la aldea global.

\section{METODOLOGÍA JURÍDICA}

La presente investigación aborda el problema de la desnaturalización de la figura jurídica del joint venture. Para abordar tal problemática en la contratación contemporánea, es menester referirse a su naturaleza jurídica, y el análisis de la misma comprende: la noción del contrato de joint venture, los problemas derivados de su definición; la historia o el origen de la figura y la adaptación de este trasplante jurídico al derecho interno colombiano; la función económica, así como los elementos, características y formación del contrato. Es a partir de allí que solo se puede abordar la discusión jurídica sobre la naturaleza jurídica del contrato de joint venture y su desnaturalización; de lo contrario, si no se estudia y analiza qué es qué no es el contrato de joint venture desde la perspectiva de su definición y de sus elementos y características, es imposible entrar a debatir sobre su desnaturalización, pues con base en estos aspectos medulares, esenciales, es que se pretende conducir esta discusión jurídica sobre un contrato de tanta relevancia en el derecho contemporáneo. Así, pues, se trata de una investigación que desde una óptica metodológica cualitativa, analítica y hermenéutica necesaria en el derecho de contratos actual, donde si bien es cierto se han acogido muchas figuras jurídicas del derecho anglosajón y europeo, han sufrido mutaciones y variaciones, o más bien adaptaciones en el derecho de contratos colombiano, y esto es lo que se demuestra con esta investigación, precisamente, la desnaturalización de la figura partiendo de su naturaleza, elementos, características y formación, y con base en estos elementos conceptuales, se presentan los problemas teóricos y prácticos que se han suscitado en el derecho colombiano, sobre todo con la utilización de la figura en el marco de la ley 80 de 1993. 


\section{NOCIÓN Y NATURALEZA JURÍDICA DEL JOINT VENTURE}

\subsection{ACERCA DE LA NOCIÓN DE JOINT VENTURE}

Definiciones sobre el joint venture existen cuantos autores han tratado el tema; cada autor, dependiendo del sistema jurídico a que pertenezca, presenta una noción de lo que es el joint venture y, algunas definiciones de la doctrina local, lo confunden con los consorcios y las uniones temporales a que se refiere la ley 80 de 1993 sobre contratación pública. Sin embargo, como se precisará más adelante, se trata de figuras jurídicas distintas, con alcances y efectos jurídicos diferentes; más bien, puede decirse que los consorcios y las uniones temporales son subespecies o modalidades de joint venture, pero en estricto rigor jurídico no lo son. Ahora bien, la mayor parte de las definiciones que trae la doctrina y la jurisprudencia se suelen centrar en las características y fines del joint venture. Igualmente, abundan las referencias al derecho anglosajón, como si se tratara de una figura jurídica exclusiva del derecho inglés o norteamericano, cuando, por el contrario, se trata de un negocio de colaboración empresarial de luenga tradición en los diversos sistemas jurídicos supérstites de nuestro tiempo, que se ha empleado en todos los sectores de la economía, así como en los distintos sistemas económicos (capitalismo, socialismo, comunismo, entre otros) de la economía global. En otras palabras, se trata de una figura jurídica de universal aplicación en el ámbito del comercio y los negocios.

La OCDE define el contrato de joint venture como "una asociación entre dos o más empresas con el objeto de realizar en común una determinada actividad a través de una nueva entidad creada y controlada por los participantes".

De acuerdo con ARRUBLA PAUCAR (2008, T. III, p. 278), el joint venture se puede definir, "atendiendo a la jurisprudencia norteamericana sobre la materia, como una asociación de personas físicas o jurídicas que acuerdan participar en un 
proyecto común, generalmente específico ( $a d-h o c)$, para una utilidad común, combinando sus respectivos recursos, sin formar o crear una corporación o el status de una partnership en sentido legal".

"Un concepto más simple lo ofrece ROWLEY quien define el joint venture como una asociación de dos o más personas para realizar una única empresa comercial con el fin de obtener una utilidad" (ARRUBLA PAUCAR, 2008, T. III, p. 279)

"Para LE PERA, el vocablo joint venture puede revestir diferentes contenidos; el primero de ellos referido al acuerdo por el que dos o más empresas se asocian para la realización de un proyecto determinado, independiente de la forma jurídica que dicha asociación pueda asumir. Otro significado sería en el derecho estadounidense una particular organización contractual para la realización de un proyecto; incluso en ciertos Estados de Norteamérica se circunscribe a la participación en actividades mineras o de proyectos" (ARRUBLA PAUCAR, 2008, T. III, p. 279).

Por último, agrega: "El joint venture es una unión o agrupación de dos o más personas, naturales o jurídicas, sin el propósito de formar una sociedad, para realizar una operación concreta en búsqueda de beneficios, asumiendo los riesgos que le son propios" (ARRUBLA PAUCAR, 2008, T. III, p. 279. En el mismo sentido, cfr. VANASCO, 2001).

Manifiesta SEGAL "que frecuentemente se limita como una asociación de dos o más personas para llevar adelante una empresa individual con fines de lucro, a cuyo efecto combinan sus activos, dinero, efectos, habilidades y conocimiento.

"En este sentido, no cabe duda de que el joint venture crea una comunidad de intereses, como señala LE PERA" (MARZORATI, 2003, T. 2, p. 287). 
Según LÓPEZ GUZMÁN (2008, p. 465), "Los joint ventures se han utilizado también para transferir tecnología y know how. Se trata de una expresión frecuentemente empleada en los contratos de colaboración empresarial; sin embargo, no hay uniformidad de criterio para definir el concepto. La expresión joint venture se usa en la esfera de los negocios internacionales para designar una especie de alianza estratégica, cumplida principalmente por sociedades de capital. La doctrina norteamericana concibe el joint venture con un criterio más amplio, porque sostiene que es posible la participación de personas naturales y no solo de personas jurídicas".

"Según los autores CABANELLAS y KELLY (1987, pp. 103 - 106), el origen de las dificultades está en que los juristas formados en otros sistemas jurídicos diferentes del norteamericano no han comprendido la ambigüedad con que se utiliza el concepto en Estados Unidos (OSORIO ARTURO, 1999, p. 54). Los joint ventures son una especie de alianza estratégica en la que se conjugan esfuerzos, capital y recursos humanos, a fin de desarrollar un proyecto en común. En Colombia son muy conocidos en las actividades minera, petrolera y ganadera. En esta última actividad se los conoce como contrato <<al partir >>" (LÓPEZ GUZMÁN, 2008, p. 466).

"La gran parte de la doctrina internacional que ha analizado la figura ha pretendido infructuosamente hacer dos cosas: desarrollar un concepto unitario y encontrar el equivalente de los joint ventures en la legislación de su país, asimilándolos a figuras preexistentes en su ordenamiento; sin embargo, no existiendo en la práctica jurídica tal concepto unitario caen en toda clase de malformaciones jurídicas al tratar de encuadrarlos en figuras con características y elementos muy distintos (OSORIO ARTURO, 1999, p. 54), como, por ejemplo, los consorcios y uniones temporales.

Aunque esto no nos debe de parecer extraño cuando se trasplantan figuras jurídicas foráneas, ya que se confunde el ejercicio del derecho comparado con la 
legislación comparada, lo cual conduce al envilecimiento de las instituciones jurídicas" (LÓPEZ GUZMÁN, 2008, p. 466).

Por su parte, MARIO DE LA MADRID ANDRADE (2005, p. 17), explica lo siguiente acerca del concepto de joint venture: "Entendemos que el joint venture es un contrato por el cual, dos o más personas físicas o jurídicas acuerdan emprender una actividad determinada, de manera conjunta, a través de los medios que también definen, para lo cual se obligan a efectuar contribuciones de diversa naturaleza, con la pretensión de alcanzar un beneficio común y, salvo pacto en contrario, participar en las pérdidas, con la posibilidad, para ambas partes, de ejercer la gestión y el control de la referida actividad o de una parte de ella".

\subsection{ANÁLISIS CRÍTICO SOBRE LA NOCIÓN DE JOINT VENTURE EN EL DERECHO COLOMBIANO.}

Examinadas las definiciones anteriores, es más conveniente desde el punto de vista del derecho mercantil contemporáneo y de la técnica legislativa moderna, ubicar la noción de joint venture dentro del concepto de contrato plurilateral de colaboración empresarial, consensual, de carácter atípico, dada su falta de regulación en el ordenamiento jurídico interno, selectivo, oneroso y de tracto sucesivo, que en la práctica profesional y empresarial se nutre del régimen de obligaciones, contratos y de las sociedades mercantiles.

Algunas definiciones pretenden identificarlo con una especie de sociedad comercial atípica, es decir, como una técnica de organización empresarial, mientras que otras, más apegadas a las instituciones del derecho privado, lo encuadran dentro de la figura jurídica del contrato. Técnica de organización empresarial o contrato, lo cierto es que el joint venture participa de ambas características, de sendos elementos, pues a partir de un contrato de joint venture se pueden organizar sociedades comerciales como vehículo de inversión, o tan sólo a partir del contrato surgen obligaciones para las partes. 
En criterio de quien esto escribe, la noción de joint venture debe contener elementos de uno y otro, ya que se trata de una figura jurídica compleja que escapa al mero contrato y a la simple técnica de organización jurídica, propia del derecho anglosajón.

De otra parte, hay quienes consideran que en el derecho de los negocios nacionales e internacionales lo más conveniente es prescindir de las definiciones (LÓPEZ GUZMÁN, 2014; RAVASSA MORENO, 2004), por cuanto los conceptos sobre las figuras jurídicas siempre están sujetos a las mutaciones que imponen los avances tecnológicos, las transformaciones jurídicas, políticas y económicas, así como a la interdependencia cultural, y no es posible mantener o petrificar un concepto, resistiendo a la pátina del tiempo, manteniéndolo incólume; por el contrario, los conceptos jurídicos dependen de dichos factores para moldearse y evolucionar.

Por ello, el derecho mercantil internacional y los instrumentos de negocios en el siglo XXI (convenios internacionales sobre contratación y negocios, verbigracia, Convención de Viena sobre Compraventa Internacional de Mercaderías, los Principios UNIDROIT de 2010, Leyes Modelo de UNCITRAL sobre arbitraje comercial, comercio compensatorio, conciliación internacional, comunicaciones electrónicas en contratos internacionales, comercio electrónico, insolencia transfronteriza, entre otros $)^{3}$, no se aventuran en las definiciones, pues terminan limitando las figuras jurídicas que se proponen y aplican en el comercio global. En consecuencia, el corsé ortopédico de las definiciones y los conceptos terminan deformando y restringiendo la evolución de figuras jurídicas como los joint ventures, desconociendo que se trata de una institución jurídica que se origina y desenvuelve a partir de las relaciones comerciales y los negocios entre empresarios, de los usos y costumbres mercantiles, y no es producto del trabajo que por antonomasia le corresponde al legislador. En otras palabras, la figura y las

\footnotetext{
${ }^{3}$ Sobre el derecho mercantil internacional, cfr. OVIEDO ALBAN, 2010.
} 
características del joint venture son tributarias del comercio, del mercado y los negocios y no de la mera labor o liberalidad del legislador, pues en últimas el legislador tan solo se limita a condensar o materializar con la ley los contratos y los usos de la actividad mercantil.

En consecuencia, otro sector de la doctrina considera que la definición de los joint ventures es inconveniente y está en contravía del derecho mercantil contemporáneo.

En conclusión, no se puede pretender imponer un concepto jurídico aislado sobre el joint venture, ajeno a las categorías y conceptos internacionales, como si se tratara de una figura jurídica local, sin conexión con los principios y normas del derecho mercantil internacional, máxime cuando su génesis y aplicación son de carácter global.

En otras palabras, un tribunal de arbitramento suizo o canadiense o español, no pueden tener criterios distintos, disímiles sobre esta figura jurídica, so pretexto de un localismo jurídico determinado. No, habida cuenta que organizaciones como la CNUDMI, UNIDROIT, la CCI, por el contrario, lo que han tratado de hacer con todas estas figuras jurídicas es armonizarlas y unificarlas para que el lenguaje jurídico sea común en cualquier país y en cualquier sistema jurídico.

Basta con revisar el Convenio de Naciones Unidas sobre Compraventa Internacional de Mercaderías, en su origen, los países de los diferentes sistemas jurídicos que allí participaron, para percatarse de inmediato que el tratamiento jurídico de estas figuras jurídicas no puede ser local, con visión jurídica estrictamente local, sino atendiendo a principios y normas internacionales. Ello justifica la existencia de los principios de internacionalidad, uniformidad y armonización a que se refiere por ejemplo, el artículo $7^{\circ}$ de la Convención de Naciones Unidas sobre Compraventa Internacional, y en general, los Principios de Unidroit, entre otros. De ahí que nuestra crítica esté orientada a precisar que en el 
derecho interno colombiano se ha desnaturalizado la figura, pretendiendo darle un tratamiento y una configuración jurídica, apartándose de las categorías y criterios del derecho mercantil internacional, lo que en un mundo globalizado no tiene sentido ni razón de ser.

Esta definición, por así decirlo, es globalmente aceptada en los distintos ordenamientos jurídicos. Así, por ejemplo, si revisamos la doctrina latinoamericana y europea sobre el particular (PAULAEUA, GHERSI, FARINA, DE LA MADRID ANDRADE, ASTOLFI, SIERRALTA, entre otros), encontramos que el concepto sobre la figura es universal, y que los estándares también lo son. De manera que sería pretensioso y estaría en contravía del derecho de la contratación con temporánea tratar de imponer criterios puramente locales, ajenos al derecho global de la contratación. Además, los principios y reglas del derecho de la contratación mercantil contemporánea así lo exigen. De hecho, normas internacionales sobre joint venture, leasing, sociedades comerciales, compraventa internacional, entre otras, están diseñadas con base en conceptos globales, aplicables a cualquier ordenamiento, en cualquier país, por cualquier empresa $u$ operador jurídico, al margen del sistema jurídico a que se pertenezca; esa es una consecuencia de la globalización del derecho y, por supuesto, de la contratación contemporánea, del sistema jurídico propuesto por los tratados comerciales internacionales; es decir, que se trata de un lenguaje jurídico global y no local. De otra parte, también se pregona la aplicación y el desarrollo de las figuras jurídicas, prescindiendo de las definiciones. Una buena muestra de lo que venimos diciendo lo constituyen los convenios sobre contratación comercial en el derecho internacional, verbigracia, Convenio de México de 1994, Convenio de Roma de 1980, Convención de Viena de 1980 sobre Compraventa Internacional, entre otras. Por ello, se ha criticado hasta la saciedad el hecho de que en la ley 80 de 1993 en su artículo $7^{\circ}$ se pretendiera subsumir la figura jurídica del joint venture, típicamente internacional, anglosajona, en los consorcios y uniones 
temporales, con categorizaciones, individualizaciones que poco o nada tienen que ver exactamente con la figura que aquí se examina a lo largo de esta investigación. Lo más sensato hubiera sido aprobar en su integridad el proyecto 119 de 1995 relativo a la modernización del Libro II del Código de Comercio, donde precisamente se incluía un régimen sobre las uniones de empresas, los joint ventures y estas formas asociativas de colaboración empresarial; sin embargo, el legislador, por temor, desconocimiento o desconexión con el derecho comparado, decidió excluir esta parte del proyecto y, por ende, no se reguló más a fondo el joint venture, acorde con los principios y reglas del derecho mercantil internacional. Dicho vacío jurídico se intentó suplir mediante el artículo $7^{\circ}$ de la ley 80 de 1993 sobre Contratación Pública. Empero, no sólo el legislador se quedó corto sino también la jurisprudencia del Consejo de Estado y de la Corte Constitucional, pues no han ahondado en las características y en la naturaleza jurídica de esta figura, limitándose únicamente a repetir el contenido del artículo $7^{\circ}$ de la ley 80 de 1993 y a reiterar los efectos jurídicos desde el punto de vista de la responsabilidad patrimonial, así como en lo concerniente a la personificación jurídica de los joint ventures.

\subsection{ELEMENTOS Y NATURALEZA JURÍDICA DEL JOINT VENTURE EN COLOMBIA}

Presentadas las definiciones anteriores, y asumida la postura correspondiente en lo que atañe a su noción, es procedente analizar y establecer lo concerniente a los elementos y la naturaleza jurídica del joint venture: Veamos:

\subsubsection{DIFICULTAD PARA SU ENCUADRE JURÍDICO EN COLOMBIA} DESDE EL PUNTO DE VISTA DOCTRINAL. En primer término, el joint venture en la doctrina jurídica local presenta el inconveniente de que intenta simplificar, unificar, o si se quiere, encuadrar, una figura jurídica típica del derecho anglosajón en un ordenamiento jurídico derivado del 
derecho continental europeo o del civil law. He ahí el primer problema jurídico, es decir, el primer obstáculo con que se encuentra el jurista, al pretender enmarcar una institución proveniente del common law al sistema jurídico romano-germánico (Sobre los sistemas jurídicos, cfr. RENÉ DAVID, 1976; SIERRALTA RÍOS y BAPTISTA, 1998; BERMAN, 1996).

Lo más aconsejable, desde el punto de vista de la práctica jurídica y empresarial contemporánea, es realizar un trasplante jurídico acorde con la naturaleza de la figura jurídica y con la realidad jurídico local donde se pretende trasplantar. En otras palabras, por defender las características y la naturaleza jurídica de una institución perteneciente a un sistema jurídico, verbigracia, del common law, no es conveniente hacer un trasplante integral, sin efectuar los ajustes y la adaptación a un sistema jurídico local donde se pretende implantar una figura jurídica. Así las cosas, resulta fundamental analizar la función y el contexto jurídico-empresarial para realizar un trasplante jurídico adecuado, pertinente, acorde con las necesidades económicas, sociales, políticas y culturales del país y del sistema jurídico donde se intenta aplicar una figura jurídica foránea. (Cfr. BONILLA MALDONADO, 2009).

El yerro en que ha incurrido la doctrina jurídica local, estriba en el hecho de pretender circunscribir el joint venture a un contrato de colaboración empresarial, o a una especie de contrato de asociación, conforme a la clasificación y tipología del Código Civil o del Código de Comercio colombianos (GIRALDO BUSTAMANTE, 2006; pp. 105 - 112; OVIEDO ALBÁN, 2010, pp. 266 y ss; PEÑA NOSSA, 2014).

El joint venture, al igual que el franchising, el leasing, el countertrade (permuta internacional), entre otras figuras jurídicas, más que contratos, son negocios empresariales flexibles, dinámicos, que se moldean de acuerdo a los intereses comerciales de los empresarios; allí reside la dificultad o el valladar con el que se 
encuentran los juristas que, apegados a la tipología contractual de los códigos no ven más allá, e ignoran la visión holística del hombre de negocios.

Aquí vale la pena resaltar que la contratación y el comercio son un derecho vivo, ágil, dinámico, que desborda incluso la propia legislación mercantil, pues ésta última no va al mismo ritmo de aquéllos, lo cual genera una crisis al interior del sistema legislativo (Al respecto, Cfr. GARRIGUES, 1971). Entonces, es un error doctrinal y jurisprudencial procurar encuadrar o limitar el joint venture a un contrato bilateral o plurilateral o a una especie de sociedad comercial de hecho, cuando la figura jurídica que aquí se estudia es mucho más compleja y dinámica, merced a los requerimientos del comercio global.

\subsubsection{POSICIÓN DE LA JURISPRUDENCIA NACIONAL COLOMBIANA. En} esta misma línea de pensamiento, el Consejo de Estado y la Corte Constitucional de Colombia, al referirse a la figura jurídica del joint venture, la han asimilado a los consorcios y uniones temporales de que habla la ley 80 de 1993 en su artículo $7^{\circ}$, en el sentido de que con dicha figura jurídica no se constituye una persona jurídica en los términos que expresan los artículo 98 y 99 del Código de Comercio colombiano, y que, mediante éstos (consorcios y uniones temporales), se agrupan empresas, sociedades mercantiles y comerciantes para presentar propuestas comerciales en procesos licitatorios ante las entidades administrativas.

Así, las cosas, en lo concerniente a la naturaleza jurídica del joint venture, la jurisprudencia del Consejo de Estado y de la Corte Constitucional, han confundido las uniones temporales y el consorcio con el joint venture propiamente dicho, imponiéndole las limitaciones jurídicas y conceptuales al joint venture mediante la referencia a éstas (consorcios y uniones temporales), cercenando, entre otros aspectos, el postulado la autonomía de la voluntad, ya que en el marco de un negocio de joint venture hay total libertad contractual para estipular lo que las 
partes consideren conveniente, verbigracia, legislación aplicable al contrato, al convenio arbitral, a la participación de inversionistas extranjeros, al objeto social, al término de duración, al vehículo jurídico de inversión (fiducia, sociedad mercantil, fundación, Ongs, entre otros), modalidad de acciones (acciones al portador, etc). Los consorcios y uniones temporales están más delimitados por la legislación colombiana y, por consiguiente, presentan más restricciones desde el punto de vista jurídico que los joint ventures. Por tanto, no es aventurado sostener que la jurisprudencia de las altas cortes (Consejo de Estado y Corte Constitucional), ha sido reiterada, elemental, no ha evolucionado y subsiste un espíritu conservador en esta materia.

En diversos fallos o sentencias del Consejo de Estado ${ }^{4}$, así como de la Corte Constitucional $^{5}$, se ha hecho referencia a esta figura jurídica, sin examinar con detenimiento los alcances y efectos del joint venture, tan sólo, como se mencionó antes, se ha aludido a las uniones temporales y a los consorcios desde el punto de vista de la responsabilidad, sin establecer diferencias y/o precisiones conceptuales en torno de la figura jurídica que aquí se examina, partiendo de la base jurídica que la relación que se establece entre las partes en estos contratos no constituyen una sociedad o asociación, o sea una persona jurídica distinta, precisamente

\footnotetext{
${ }^{4}$ A guisa de ejemplo podemos citar los siguientes fallos del Consejo de Estado: Sala de lo contencioso administrativo, sección tercera, consejero ponente: Alier Eduardo Hernández Enríquez, Bogotá, D. C., siete (07) de diciembre dos mil cinco (2005); Sala de lo contencioso administrativo, sección tercera, sala plena, consejero ponente: Enrique Gil Botero, Bogotá D.C., veinticinco (25) de septiembre de dos mil trece (2013); Sala de lo contencioso administrativo, sección primera, consejero ponente: Marco Antonio Velilla moreno (e), Bogotá, d.c., veinticuatro (24) de mayo de dos mil doce (2012); Sala de lo Contencioso Administrativo, sección primera, consejero ponente: Rafael E. Ostau de la Font Pianetta, Bogotá, D. C., tres (03) de noviembre de dos mil once (2011).

${ }^{5}$ Corte Constitucional, sentencia C-949/01; Acumulados d-516 y d-523, tema: los consorcios y uniones temporales como sujetos pasivos de obligaciones tributarias. Actores: Camilo Ernesto Ramírez, Gaspar Caballero s. y Marcela Anzola Gil. Magistrado ponente: Antonio barrera Carbonell. Aprobada en Santafé de Bogotá, d. c., a los veintidós (22) días del mes septiembre de mil novecientos noventa y cuatro (1994); Sentencia T-512 de 2007, Referencia T-1533887, MP. MANUEL JOSE CEPEDA ESPINOSA, Bogotá, 6 de junio de 2007.
} 
porque no hay una búsqueda de una utilidad sino un esfuerzo conjunto para obtener producción.

Las altas Cortes en el ordenamiento jurídico colombiano, se ha apoyado en diversos planteamientos esbozados en la doctrina,bajo el entendido que se trata de un contrato atípico, de colaboración, oneroso, bilateral o plurilateral, consensual, de tracto sucesivo y con fines de lucro, pero estas características insertas en su definición no permiten establecer realmente su naturaleza jurídica, desentrañar y abarcar la complejidad de los negocios de joint venture, sobre todo cuando está inmerso en un grupo de contratos y cuando se presenta, por ejemplo, un fraccionamiento voluntario de la ley o depeçage ${ }^{6}$ (Cfr. PAULEAU, 2003). Y esa dificultad primigenia se desprende del hecho de que este contrato, al igual que los mencionados anteriormente, proviene del derecho anglosajón; es decir, de un sistema jurídico ajeno al nuestro, con categorías, principios e instituciones bien diferentes al sistema jurídico continental europeo.

No obstante, en contra se arguye que merced a la mutua interdependencia jurídica entre las distintas familias jurídicas, los contratos mercantiles contemporáneos y, en particular, los atípicos tienen las mismas características, contenido, alcances y efectos jurídicos, en virtud de la globalización jurídica, la transnacionalización del derecho y la denominada lex mercatoria (SANTOS, 1999, pp. 104 - 107; FARIA, 2001). Es un argumento real, práctico, que evidencia la amplificación del derecho mercantil internacional y de sus categorías jurídicas básicas, en especial las atinentes al sistema de contratación global. Sin embargo, la discusión jurídica a este respecto hay que situarla en el ámbito de los trasplantes jurídicos y cuál es la función jurídica y económica que éstos deben cumplir en un ordenamiento jurídico como el nuestro que, como es sabido, es receptor, importador y no creador.

\footnotetext{
${ }^{6}$ Es un término jurídico en materia de contratación internacional, que se refiere a la facultad que tienen las partes en un contrato de estipular que diversas cláusulas del contrato estén sometidas a ordenamientos jurídicos diferentes. Asi, por ejemplo, el Convenio de Roma de 1980. Al respecto, cfr. RAVASSA, 2004.
} 
Estas consideraciones permiten detallar aquellos elementos que identifican la figura del contrato joint venture, de la siguiente manera:

3.3.3. EL ÁNIMO DE LUCRO. Otro aspecto sobre el cual merece la pena detenerse es el relativo al "lucro", como elemento esencial (C. C., art. 1501) y característica que está involucrado en el concepto. La mayoría de la doctrina, sostiene que el joint venture es un contrato de colaboración donde las partes implicadas invierten recursos, capital y conocimiento, con objeto de obtener un "lucro". Éste, se encuentra ligado al ejercicio de la actividad mercantil y podría decirse que constituye la esencia de las operaciones y negocios mercantiles. Sin embargo, en la contratación global este concepto, este elemento que otrora se erigía en el móvil principal del negocio, ha variado, dadas las nuevas condiciones de la economía global y la permanente mutabilidad de la contratación en el siglo XXI. El "lucro" ya no es hoy día el componente exclusivo y determinante para la creación y constitución de un negocio de joint venture, pues muchas alianzas estratégicas se instituyen y desarrollan con fines económicos diversos, ajenos al concepto de "lucro", por lo común inherente a la organización y gestión de empresas conjuntas.

Así las cosas, en la contratación contemporánea es habitual encontrar asociaciones de empresas (joint ventures) dedicadas a la ejecución de proyectos de interés social y cultural, donde el "lucro" no reviste especial interés para los copartícipes. Lo anterior, es una lógica consecuencia del naciente modelo global denominado capitalismo social, capitalismo humanizado o economía social.

En la contratación mercantil del siglo XXI se busca la satisfacción de un fin económico, la cooperación y la solidaridad, el interés general y no exclusivamente el interés individual, plexo central del capitalismo salvaje. En resumen, el leitmotiv de los contratos de asociación (joint venture) y de las empresas conjuntas no son 
las ganancias y el "lucro", sino que, por el contrario, el propósito es producir beneficios sociales (Acerca de la empresa social Cfr. YUNUS, 2011). En tal sentido, coincide el derecho comunitario (principios y reglas) europeo (Cfr. RAVASSA, 2004).

En conclusión, sobre este particular, conviene manifestar lo siguiente: en los contratos y negocios de joint venture puede haber o no un propósito de lucro, elemento del contrato como tal, pero siempre está presente un fin económico, desde el punto de vista del derecho mercantil actual.

Recordemos que, según la doctrina actual (RAVASSA, 2004), empresa es toda actividad que tiene un fin económico, al margen de que exista lucro o no. En este sentido adhiero al moderno concepto de empresa del derecho mercantil europeo, donde el fin económico es el factor primordial, y el joint venture es, finalmente, una empresa conjunta.

3.3.4. EL AFFECTIO SOCIETATIS. De otra parte, un amplio sector de la doctrina considera que el joint venture está fundado en el ánimo de asociarse para desarrollar un proyecto y obtener una utilidad. Se aduce que por tratarse de una forma asociativa - atípica -, de todas maneras está presente el affectio societatis, al igual que ocurre con las sociedades comerciales. Sin embargo, este aspecto ha sido cuestionado en la doctrina contemporánea y asimismo se ha desdibujado en el nuevo derecho contractual. Ciertamente, lo que realmente motiva la constitución y organización de un joint venture no es el affectio societatis sino el affectio cooperationis, o sea, el ánimo de cooperar en una actividad económica. Así los copartícipes constituyan una sociedad comercial como vehículo jurídico para el funcionamiento del joint venture, la motivación inicial no es la de constituir una sociedad mercantil sino la de realizar un negocio de cooperación. Por ello, el contrato de joint venture es tan versátil, que le permite a los asociados 
adoptar la forma o pactar el negocio que más se ajusta a sus necesidades comerciales.

Esta situación es compartida por la doctrina internacional (ASTOLFI, 1983, p. 7), al manifestar que "no corresponde la subsunción del contrato en un esquema societario, en cuanto no solo conduciría a una errónea consideración unitaria de los contractual joint ventures y de los joint ventures corporations, sino que no tendría en cuenta la circunstancia de que la convención del contrato de joint venture está motivada, en la generalidad de los casos, en la propia voluntad de los contrayentes de convenir en una relación de colaboración que quiere excluir una relación social. Ni siquiera convence la reconducción de esta regulación de intereses dentro de tipos contractuales como el consorcio con actividad externa, cuyo modelo subyacente, se adapta sólo en parte a la relación negocial”.

Igualmente, SIERRALTA RíOS (1996, p. 67) expone que "no existe entre los sujetos vinculados el ánimo de formar una sociedad, justamente optan por esta figura porque no desean formar un ente jurídico autónomo. Está ausente la affectio societatis, no existe el ánimo de formar una sociedad, pues se busca la realización única de una operación determinada". Similar situación acontece en el derecho societario comparado, pues el ánimo de asociarse no es concluyente para la creación y organización de una sociedad comercial, verbigracia, en el derecho societario estadounidense (Cfr. REYES VILLAMIZAR, 2006, pp. 102 - 103), postura que en mi percepción, es real y frecuente en la formación de los joint venture.

3.3.5. EL OBJETO EN EL JOINT VENTURE. Otro de los puntos que amerita la atención respecto del concepto de la doctrina sobre el contrato de joint venture es el concerniente al objeto. En tratándose de las sociedades comerciales en el marco del derecho continental europeo (civil law), es sabido que el objeto social debe ser determinado, excepto para las empresas unipersonales y las sociedades por acciones 
simplificadas SAS (En torno de las sociedades por acciones simplificadas, cfr. LÓPEZ GUZMÁN, 2012). La mayoría de las legislaciones sobre derecho de sociedades en Latinoamérica gozan de los mismos rasgos característicos (Cfr. REYES VILLAMIZAR, 2006). En los joint ventures, dada su atipicidad contractual y societaria, no es posible hablar de que el objeto social deba ser determinado o indeterminado, salvo que los inversionistas hayan decidido utilizar un tipo societario específico, en el que la legislación mercantil exija que el objeto social deba estar claramente delimitado.

En principio, se puede argüir que la determinación y especificidad en el objeto social están sujetas al hecho de que las partes elijan un tipo societario como vehículo de inversión y negocios. Así, pues, la determinación o indeterminación del objeto social es un asunto complejo, difícil, si se quiere, alambicado, puesto que depende de la implementación de un tipo societario para la realización del negocio de joint venture. En primer término, habida cuenta de la atipicidad contractual del joint venture resulta equivocado sostener que el objeto social de esta modalidad de asociación empresarial obligatoriamente debe ser determinado o no, pues ello depende en forma directa de la sociedad comercial que los inversionistas van a constituir para el desarrollo del joint venture y de la legislación específica del país donde va a operar el joint venture; sin embargo, la situación se complica aún más cuando el contrato de joint venture es internacional y, por ende, se celebra y ejecuta en varios países, habida cuenta del enjambre legislativo o de la torre de babel jurídica que de allí se deriva y que resulta de difícil solución para los operadores jurídicos (Para un análisis sobre la problemática en la contratación internacional y en los joint ventures a nivel global, cfr. KOZOLCHYK, 2006; GÓMEZ-URRUTIA, 2000; MARZORATI, 1996; RODRÍGUEZ RODRIGO, 2004).

Empero, lo expuesto anteriormente no es solo el problema jurídico que prima facie plantea el concepto de joint venture, sino también el concerniente a la extralimitación en el objeto social por parte de los administradores. Si el objeto 
social en el negocio de joint venture es indeterminado, no puede hablarse propiamente de una extralimitación en el objeto, de la tesis ultra vires; por el contrario, si el objeto social es preciso, específico, o sea, determinado, sí puede hablarse de una extralimitación en el objeto y las consecuencias jurídicas en uno y otro caso son diferentes (Respecto del objeto social y la teoría ultra vires, cfr. GIL ECHEVERRY, 2012); es decir, la responsabilidad contractual y societaria estará directamente ligada al hecho de la determinación o indeterminación en el objeto consagrado en el contrato de joint venture.

Por consiguiente, el blindaje jurídico previsto para las sociedades de capital, así como la responsabilidad de los administradores en el marco de un contrato de asociación o empresa conjunta, podrán menguarse por las actuaciones ultra vires de los socios y administradores que integran el joint venture.

En síntesis, se incurre en grave imprecisión jurídica y conceptual al indicar que en el contrato de joint venture el objeto social debe estar plenamente determinado, como si se tratara de un tipo societario, conforme a lo previsto por el artículo 110 , numeral $4^{\circ}$ del Código de Comercio colombiano ${ }^{7}$.

3.3.6. TÉRMINO DE DURACIÓN. Algunos autores, al referirse al concepto de joint venture y, en particular, cuando éste se desarrolla por intermedio de una sociedad comercial, consideran que el término de duración puede ser indefinido, por cuanto algunos tipos societarios y algunas legislaciones así lo permiten. A este respecto cabe precisar que el término de duración del joint venture está sujeto a la ejecución del proyecto; lo que realmente permite determinar el término de duración de un contrato de joint venture no es la sociedad mercantil vehículo de

\footnotetext{
${ }^{7}$ El artículo 110, numeral $4^{\circ}$ del Código de Comercio, estipula lo siguiente: "La sociedad comercial se constituirá por escritura pública en la cual se expresará: 4) El objeto social, esto es, la empresa o negocio de la sociedad, haciendo una enunciación clara y completa de las actividades principales. Será ineficaz la estipulación en virtud de la cual el objeto social se extienda a actividades enunciadas en forma indeterminada o que no tengan relación directa con aquél".
} 
inversión el negocio, como tampoco se puede afirmar que el término de duración está estrictamente vinculado a la legislación del país anfitrión de la inversión o al ordenamiento jurídico del país donde se está ejecutando el contrato (lex loci solutionis). Lo que determina el término de duración de esta operación de negocios es, sin duda, el proyecto, es éste y nada más lo que nos puede permitir establecer el término de duración del proyecto, y puede ser de mayor o menor duración incluso a la existencia misma de la sociedad comercial que sirve de instrumento para el progreso del negocio.

Por tanto, no resulta apropiado referirse en la definición al término de duración del contrato, puesto que ello depende del tipo de joint venture y del proyecto que se pretende llevar a cabo; ni tampoco es conveniente afirmar que éste debe ser definido o indefinido, merced al tipo societario utilizado, toda vez que como se indicó con anterioridad, ello está directamente ligado al proyecto en sí mismo.

3.3.7. EL RIESGO. En lo tocante al riesgo no hay discusión, porque en el contrato de joint venture, al igual que con cualquier otro negocio $u$ operación mercantil, está presente el riesgo; es inherente a la realización de cualquier negocio inversión, y en ello coincide con las forma societarias tradicionales que, no obstante los estudios de mercadeo y el análisis económico, subsiste un alto grado de incertidumbre en lo que respecta al éxito del contrato.

El riesgo compartido se refiere a la incertidumbre económica y empresarial para el desarrollo de un proyecto. Es factible que las proyecciones financieras, los análisis de mercadeo y, en general, toda la investigación empresarial y económica sean en teoría un éxito total; no obstante lo anterior, la realidad siempre difiere de la teoría, y los imprevistos económicos suelen modificar sustancialmente las cifras y estudios más precisos. 
Los negocios, la economía y el mercado fluctúan, se transforman; de hecho, los negocios bursátiles son el mejor ejemplo de lo que aquí se expresa. El riesgo y hasta el medio ambiente son factores a tener en cuenta, y por ello cuando las empresas se asocian comparten las utilidades pero también los riesgos y vicisitudes que se puedan presentar. Así, por ejemplo, las compañías y joint ventures que se dedican a la explotación minera y petrolera en Colombia corren el riesgo de que después de haber efectuado ingentes inversiones, el proyecto no se puede ejecutar, por ejemplo, porque no se hizo la consulta previa que ordena la Constitución y la ley con las comunidades indígenas o negritudes de la zona, lo cual obstaculiza el desarrollo y la inversión. Sin embargo, como es sabido, el desarrollo debe ir de la mano, o sea, realizarse en forma simultánea con la protección al medio ambiente y los recursos naturales no renovables (Cfr. MORALES ALZATE, 2014).

3.3.8. PERSONAS Y CAPACIDAD EN LOS JOINT VENTURE. El contrato de joint venture requiere, como cualquier acto o negocio jurídico, que la persona natural o jurídica que se asocia en esta empresa conjunta, sea legalmente capaz; que consienta en dicho acto o declaración y su consentimiento no adolezca de vicio; que recaiga sobre un objeto lícito; y que tenga una causa lícita. $Y$ en lo que atañe a la capacidad, es incuestionable que los socios o inversionistas que se aventuran en un negocio de joint venture, deben gozar de la capacidad legal para celebrar el contrato, sea en calidad de persona natural o de persona jurídica. En este orden de ideas, uno de los aspectos que no se debate en la doctrina nacional (PARRA, 2004; PEÑA NOSSA, 2014; OVIEDO ALBÁN, 2012; OSORIO MORENO, 2008), es el concerniente a los problemas derivados de la incapacidad en el marco de los joint ventures, y máxime si se trata de un contrato internacional, donde concurren diferentes ordenamientos jurídicos y disposiciones de orden público que, como es lógico, son heterogéneas. 
Conforme con lo expuesto, nada se dice o se puede entrever sobre los incapaces, tanto si se trata de un incapaz absoluto, de una sociedad comercial que se encuentra en etapa de liquidación o de un administrador que celebra el contrato de joint venture que no tenía capacidad para hacerlo.

Prima facie la discusión no parece tener importancia o relevancia, máxime si se tiene en cuenta que cada legislación ofrece soluciones diferentes. Ello es una falacia, porque el debate sobre el particular, estrechamente vinculado al concepto mismo de la figura del joint venture, sí merece ser analizado, discutido, ya que lo que se ha pretendido por parte de la jurisprudencia sobre el joint venture, es que el concepto debe ser universal, global, debe estar armonizado y unificado conforme a los lineamientos que nos ofrece el derecho mercantil internacional, que está sustentado en principios y normas uniformes, de aplicación integral, global si se quiere, y donde están proscritas las concepciones jurídicas exclusivamente locales, ya que por naturaleza ello atenta contra la filosofía y esencia del derecho mercantil o de los negocios internacionales (Cfr. FERNÁNDEZ DE LA GÁNDARA y CALVO CARAVACA, 1995).

El punto no es fácil de resolver, y hay que analizarlo desde varios ángulos. Así, por ejemplo, si un incapaz absoluto en razón a la edad o a su condición mental (discapacitado mental), celebra un contrato de joint venture, dicho negocio jurídico es válido; es decir, cumple con los requisitos de validez que se indican en el artículo 1502 del Código Civil colombiano o, por el contrario, habida cuenta que no se configura una persona jurídica de los asociados individualmente considerados.

En apariencia, se puede optar por la tesis de la sociedad de hecho, es decir, por aplicar las normas e interpretación de la sociedad de hecho al contrato de joint venture y por esa vía, sostener que los incapaces no pueden ser socios de una joint venture, excepto si se configura una persona jurídica como una sociedad anónima, una SAS, una sociedad de responsabilidad limitada, o si el incapaz es socio comanditario por conducto de representante legal. 
El asunto no es claro, porque no existen disposiciones específicas del Código Civil o del Código de Comercio que nos permitan hacer este tipo de remisiones legales, y por ende, aplicar dichas normas al contrato de joint venture, donde es esencial la autonomía de la voluntad, o sea, lo que las partes tengan a bien establecer, obviamente sin violentar el orden público y las buenas costumbres, de acuerdo a lo previsto por el artículo 16 del Código Civil colombiano.

Y tampoco es fácil sostener que las empresas que están en liquidación no pueden conformar una joint venture, según los dictados del artículo 250 del Código de Comercio, por cuanto no es cierto que las joint ventures sean otra modalidad de sociedades comerciales.

A mi juicio, en virtud de la amplia autonomía de la voluntad en el contrato de joint venture, los incapaces, sean personas naturales o jurídicas, pueden ser socios de este tipo de operaciones y negocios mercantiles, y dado el vacío legal y jurisprudencial sobre la materia, tampoco se puede sostener que existen restricciones legales al respecto. Mi postura al respecto es que sí pueden ser parte en un negocio de joint venture, por intermedio de su representante legal y que los terceros, desde el punto de vista de la responsabilidad, podrán ver protegidos sus intereses mediante una garantía, verbigracia, una fiducia de garantía.

Mucho se dice acerca de la supuesta protección o del supuesto blindaje que tienen los terceros en las sociedades de capital (anónima, SAS, limitada, en comandita); sin embargo, ese blindaje y esa protección se ven seriamente menguadas cuando se trata de sociedades de papel, de sociedades comerciales que en realidad no tienen un verdadero respaldo patrimonial. Entonces, nada obsta para que los terceros se blinden mediante cualquier tipo de garantía real ${ }^{8}$, cuando, por ejemplo, alguno de los socios sea un incapaz.

\footnotetext{
${ }^{8}$ Cfr. Ley 1676 de 2013 sobre garantías mobiliarias en Colombia.
} 
Por los planteamientos antes mencionados, en lo concerniente a la naturaleza jurídica sobre los joint ventures, se puede precisar lo siguiente: son contratos consensuales, atípicos, bilaterales o plurilaterales, con naturaleza jurídica propia, onerosos, aleatorios y de colaboración empresarial (OSORIO ARTURO, 1999, pp. $63-64)$.

Veamos:

A) CONSENSUAL. Ciertamente, se puede afirmar que se trata de un contrato eminentemente consensual, es decir, que se perfecciona por el mero acuerdo de voluntades, y así opina la doctrina nacional e internacional (OSORIO MORENO, 2008; PEÑA NOSSA, 2014; PARRA, 2004; OSORIO ARTURO, 1999). Sin embargo, es una tendencia o una tesis que no corresponde exactamente a la realidad, que riñe con la práctica y las costumbres mercantiles. Cuando varias empresas se asocian para desarrollar un proyecto en común, es probable que una de las partes, por ejemplo, la parte dominante o con mayor capacidad financiera, sea una entidad estatal o una compañía multinacional. En sendos casos no hay libre discusión sobre las condiciones del negocio de joint venture; por el contrario, sea la entidad estatal o la compañía multinacional, se impone la voluntad y las condiciones de la parte fuerte en el contrato; en otras palabras, los potenciales asociados contratan e integran el joint venture bajo las reglas y condiciones o cláusulas prediseñadas por la parte dominante en el contrato, o por el grupo empresarial que acepta su ingreso al negocio u operación de joint venture. Difícilmente hallamos contratos de esta clase donde las partes están en paridad de condiciones y donde pueden deliberar libremente sobre el clausulado del contrato; es un escenario jurídico ideal, pero irreal, que no corresponde a la práctica y a los usos y costumbres mercantiles.

Y el problema no es la posición de dominio, sino el abuso de ella en el clausulado del contrato (Const. Pol., art. 333). Por consiguiente, es incierto, 
inexacto hablar de la consensualidad del contrato; más bien, lo que ocurre es que se trata de un contrato de adhesión, donde el grupo empresarial que tiene un empoderamiento del mercado, o la entidad gubernamental, imponen las reglas y condiciones del negocio; si el interesado, esto es, el potencial socio inversionista cumple con los requisitos objetivos de contratación, es aceptado y, por ende, puede empezar a integrar el negocio de joint venture. Es fácil evidenciar esta situación, cuando empresarios colombianos y extranjeros suscriben acuerdos de unión temporal 0 consorcios, donde el nivel de participación o utilidad es mayor en el extranjero, en tratándose de propuestas presentadas al Estado en materia de procesos contractuales públicos, hoy fácil de consultar en la página de Colombia compra eficiente, donde se publican los documentos del proceso y en particular la oferta ganadora.

B) ATíPICO. Indudablemente es un negocio atípico en la legislación interna, en la legislación local. Ni el Código de Comercio ni el Código Civil ni el estatuto de contratación pública (Ley 80 de 1993) regulan este tipo de contrato. Sin embargo, no puede pregonarse lo mismo en torno de los contratos internacionales de joint venture, donde, por el contrario, sí se han expedido algunas normas sobre el particular, en especial en el ámbito del derecho comunitario europeo, y la pregunta que cabe formularse es si en el ámbito internacional el contrato de joint venture es más bien un contrato típico. No resulta descabellada, aventurada, o no constituye un despropósito jurídico el sostener que el contrato internacional es típico por la amplia regulación que de él se ha hecho en el derecho comunitario internacional (Acerca de la regulación en el contexto europeo, cfr. GUARDIOLA SACARRERA, 1998), situación bien distinta en el derecho colombiano.

C) Bilaterales O PLURILATERALES. Al respecto no hay duda; si participan tan solo dos compañías, el contrato es bilateral, pero si son varios socios, el contrato es plurilateral. $Y$ a juicio de quien esto escribe, el negocio o la operación mercantil de joint venture, puede estar integrado por 
personas capaces e incapaces, así como por inversionistas nacionales y extranjeros.

D) NATURALEZA JURÍDICA PROPIA. Son de naturaleza jurídica propia, y en esto hay que hacer hincapié, dado el amplio margen de la autonomía de la voluntad. Se confunde la figura a menudo con los consorcios y las uniones temporales de que habla la ley 80 de 1993; sin embargo, éstos son subespecies o modalidades de asociación, si se quiere, subtipos de joint venture, pero no joint ventures en estricto rigor jurídico, pues el postulado de la autonomía de la voluntad es más completo, más holgado en el contrato de joint venture que en las sociedades de hecho, o en los consorcios y uniones temporales. Lo más sano y apropiado para la dinámica empresarial y de los negocios, es que el joint venture goce de completa independencia, autonomía y que no se confunda con otro tipo de negocios jurídicos, pese a que guarde cierta similitud con algunas figuras jurídicas, verbigracia, las cuentas en participación o la sociedad comercial de hecho.

E) ONEROSOS. Tampoco hay duda respecto a la onerosidad del contrato, no obstante que en algunos casos se puede predicar que no existe un lucro, pero la falta de lucro no es sinónimo de fin económico. En otros términos, puede tener o no un fin de lucro, implica unas cargas u onerosidad para las partes o los asociados, pero siempre está presente un fin económico. Los asociados siempre asumen cargas y obligaciones en el negocio de joint venture, lo cual genera unos costos económicos.

F) ALEATORIOS. El contrato de joint venture está sujeto al alea. Sobre este particular no hay discusión y los criterios doctrinales y jurisprudenciales son unánimes al respecto. Al ejecutarse las obligaciones en forma periódica durante el desarrollo del proyecto, el contrato y las obligaciones derivadas de él están sujetos al alea, dependen de muchos factores externos. Por 
ende, le es aplicable a este negocio jurídico la teoría de la imprevisión y la cláusula hard ship $^{9}$ en los joint ventures internacionales.

G) COLABORACIÓN EMPRESARIAL. La mayoría de los contratos contemporáneos son de colaboración, de cooperación, y más aún en tratándose de los contratos de joint venture, donde el animus cooperationis es un elemento esencial del contrato.

Respecto de las características antedichas podemos realizar las siguientes críticas:

Como primera medida, se ha dicho hasta el cansancio que el contrato de joint venture es consensual y, por ende, informal, que no requiere de ningún formalismo o del cumplimiento de ningún requisito legal específico para su formación. Dicho concepto es en el fondo puramente teórico, habida cuenta que la solemnidad o solemnidades están sujetas al ordenamiento jurídico de cada país, es decir, a la ley del foro donde se va a llevar a cabo el contrato de joint venture, o sea, a la lex fori. Sin embargo, la situación se vuelve aún más compleja cuando en el contrato participan empresas de diversos países y cuando el contrato de joint venture se debe ejecutar en diferentes territorios 0 zonas geográficas, sujetas a ordenamientos jurídicos diferentes y, en algunos casos, a sistemas jurídicos disímiles. Supongamos el siguiente ejemplo a nivel empresarial: la empresa A de España celebra un contrato de joint venture con una compañía estadounidense, una compañía inglesa, una francesa, una japonesa y dos compañías colombianas para la construcción de un metro internacional que va desde Colombia hasta Ecuador y Perú. El proyecto se ha previsto desarrollar en 5 años. Qué legislación aplicamos? Y, por ende, puede decirse que el contrato es meramente consensual sin tener en cuenta la parte o partes dominantes en el contrato, así como el hecho de que los ordenamientos jurídicos inglés y norteamericano son más flexibles y menos formalistas que el español y el colombiano? La respuesta no es tan sencilla. Las compañías multinacionales tienen formatos prediseñados para la

\footnotetext{
${ }^{9}$ Según los principios de Unidroit, la claúsula Hard Ship tiene como propósito que el juez o el tribunal de arbitramento revisen y modifiquen las condiciones del contrato cuando ocurran circunstancias imprevistas.
} 
contratación global, de ahí que la doctrina (PPERALES VISCASILLAS, 1996) hablan de la batalla de los formularios, que no es más que el deseo de imponer en un contrato internacional las condiciones y formalidades a la parte más débil en el negocio internacional. Y cuando en el contrato de joint venture es menester, por ejemplo, la constitución de una sociedad comercial, ello también demanda ciertos formalismos que se deben cumplir, so pena de que el contrato pueda ser declarado nulo, inexistente o ineficaz. Entonces, la conclusión generalizada de la doctrina y de la jurisprudencia en el sentido de que el contrato es puramente consensual no deja de ser una tesis equivocada si se examina desde la realidad empresarial y de los negocios.

En segundo lugar, y como se explicó en esta investigación, el elemento affectio societatis no siempre está presente en esta clase de operaciones mercantiles, sobre todo si se tiene en cuenta que este tipo de negocios son hoy más de colaboración y cooperación, ya que no existe el ánimo de formar una empresa, pues se busca la realización única de una operación determinada, no da lugar a una sociedad o persona jurídica nueva. En lo atinente a la característica de la mercantilidad, también es un asunto discutible, teniendo en cuenta que muchas asociaciones de empresas no se efectúan con propósitos exclusivamente de lucro sino también de solidaridad, de cooperación, con fines de interés general y no de lucro individual. Entonces, hasta qué punto se puede seguir sosteniendo el carácter puramente mercantil del contrato cuando la realidad comercial y empresarial hoy es otra.

\section{EVOLUCIÓN Y DESARROLLO DEL JOINT VENTURE}

Para una comprensión más integral de cualquier figura jurídica siempre es menester adentrarse en el origen y evolución de las instituciones jurídicas; por lo regular la mayor parte de la doctrina suele reiterar y dar por sentado los precedentes históricos sobre el joint venture. 
Sin embargo, cuando se revisa con detenimiento, cuando se escudriña en las bases históricas, se genera una ruptura de paradigmas, puesto que el rastreo y el análisis histórico siempre terminan revelando nuevas realidades, hechos ignotos y nos conducen por caminos otrora intransitados por la mayor parte de la doctrina.

Se ha dicho por doquier que el joint venture surgió en el derecho inglés con las sociedades partnerships (PAULEAU, 2002); sin embargo, si se estudia con más detenimiento, hallamos que la figura jurídica del joint venture se remonta a los orígenes del comercio (OSORIO ARTURO, 1999); desde tiempos inmemoriales los fenicios tuvieron un importante desarrollo económico y de los negocios allende las fronteras mediante el comercio marítimo; en el Código de Hammurabi se hallan referencias al negocio societario y de colaboración por intermedio de la asociación entre personas que al final del negocio reparten las utilidades, ganancias o pérdidas.

En la Edad Media surgió la commenda donde un socio capitalista le proporcionaba recursos a otro socio que tenía el conocimiento de un ramo del comercio y que se aventuraba a viajar para invertir en un negocio; al culminar el viaje los socios se repartían las utilidades de la empresa conjunta (BERMAN, 1996).

En el derecho moderno surgen las sociedades mercantiles $y$, en particular, las partnerships que, según la mayoría de la doctrina, constituyen el origen moderno de los joint ventures.

A este respecto, manifiesta JORGE MIQUEL RODRÍGUEZ (1998, pp. 81 - 83):

"No hay unanimidad a la hora de fijar los antecedentes históricos del joint venture. Es común referirse a las Merchant Ventures del siglo XVII como su precedente más inmediato. No obstante, aún ha habido quien ha retrocedido más en el tiempo señalando la commenda babilónica, la societas unius rei romana o la commenda medieval. Se ha afirmado 
mayoritariamente que su origen es genuinamente americano, aunque también se ha hablado, en fin, de un origen mixto de la figura.

"Ciertamente, podemos buscar - y encontrar paralelismos entre todas las instituciones mencionadas y la joint venture, pero la primera reflexión debe ser necesariamente de carácter global. La joint venture es una figura cuya finalidad económica se remonta a los mismos orígenes del comercio. En su sentido más amplio, el hecho de que dos o más personas se asocien y compartan la suerte de un negocio, es tan antiguo como el comercio mismo.

Así, es evidente que, a grandes rasgos, la finalidad económica no es exclusiva de ninguna de las figuras mencionadas, y que únicamente varía el tratamiento jurídico que se da a cada una de ellas. A individualización de la joint venture, su nacimiento jurídico, se debió a una creación de los tribunales estadounidenses a finales del siglo XIX; como medio de resolver una necesidad económica surgió en cualquier momento anterior.

Las instituciones con las que pueda tener puntos en común fueron, a grandes rasgos, los paradigmas de su tipicidad de su época. En principio los puntos de coincidencia son los que puedan existir con cualquier figura de carácter asociativo; por ello, a la hora de buscar un origen común entre la joint venture y otras figuras históricas, debemos fijarnos en primer lugar en la existencia o no de un fondo patrimonial común. Debemos, asimismo, tener presente la inexistencia en los períodos estudiados de los conceptos de personalidad jurídica y limitación de responsabilidad, al menos como los entendemos actualmente.

"Es paradójico observar, que la joint venture en su esencia tiene más puntos en común con la societas o la commenda que con una sociedad anónima $o$ de responsabilidad limitada. Podemos encontrar distintas explicaciones a esta afirmación. Fundamentalmente debemos referirnos a 
un fenómeno ya conocido: la moderna sociedad anónima se inspira en la que concibieron los legisladores del siglo XIX, que a su vez se creó tomando elementos de las compañías coloniales de los siglos XVII y XVIII.

En definitiva, la sociedad anónima, con las características con las que fue introducida a finales del siglo XIX, y con ella la generalización de la limitación de responsabilidad, rompen una línea que se había seguido hasta ese momento en cuanto a la organización de las formas asociativas con fines comerciales".

Luego añade (MIQUEL RODRÍGUEZ, 1998, pp. 95 - 96):

“(...) En definitiva, a finales del siglo XIX los tribunales estadounidenses bautizaron la expresión tal como es conocida actualmente en el ámbito del comercio internacional. La cuestión que se podría plantear es si al denominarla así se remitieron conscientemente a las Merchant Adventures - la designaron de esa manera porque era una forma, meramente descriptiva, de definir la figura.

"Aún en los últimos años del siglo XIX, coincidiendo con la realización de obras públicas de gran envergadura (y con la generalización de la limitación de la responsabilidad), se produce el paso a la siguiente fase de evolución de la figura: el simple acuerdo de joint venture pasó a desarrollarse en forma de sociedad de capital, creándose las denominadas joint venture corporations.

La joint venture nace como tal jurídicamente por la razón señalada de evitar la doctrina ultra vires. La creación jurisprudencial coincide en el tiempo con la emergente generalización de las sociedades de capital. Se acude, ante la facilidad de constitución de personas jurídicas en las que se limita la 
responsabilidad de las personas físicas o jurídicas que la integran, a la combinación de joint venture y corporation, lo que crea nuevos problemas.

La realidad iba, una vez más, por delante del derecho. Se produjo la circunstancia de que en el momento en que empezaba, con vacilaciones, a reconocerse la existencia de una nueva forma de asociación, la joint venture, como un aliud en relación a la partnership y a la corporation, aparecieron las primeras manifestaciones de combinación entre las dos últimas precisamente para constituir joint venntures. La admisión de la creación de joint venture corporations no fue automática; antes al contrario, dio lugar a una larga discusión, que aún se mantiene".

En el mismo sentido expresa FARINA (1999, p. 778):

"La jurisprudencia norteamericana comienza a utilizar la expresión joint adventure a principios del siglo XIX. Luego, la jurisprudencia y la práctica mercantil abreviaron la frase utilizando la expresión joint venture, la cual pese a que quizás es más correcta la anterior - se consagró definitivamente no sólo en los Estados Unidos, sino en todo el mundo".

Conforme con lo expuesto acerca del origen de la figura, surgen varias cuestiones jurídicas que merece la pena estudiar:

En primer término, hay quienes son adversarios del historicismo, porque dan por sentado que no existe discusión sobre el origen de la figura jurídica; asimismo se cree que cualquier referencia al punto es innecesaria y está demás, pues no contribuye al debate sobre el desarrollo y la práctica empresarial de los joint ventures. No obstante, tal concepción es errónea, ya que al adentrarse en los vericuetos y en los resquicios que nos ofrece la historia jurídica, se llega a conclusiones bien diferentes sobre los conceptos que sustentan esta figura 0 cualquier otra. 
Así las cosas, el primer debate que se plantea, surge en torno al origen inglés o norteamericano de esta figura jurídica, así como a la expansión internacional que ésta ha tenido en el siglo $X X$ y comienzos del $X X I$, en virtud del fenómeno de la globalización de los mercados y la producción. Ciertamente, el origen de la figura se encuentra en la antigüedad; lo que ocurre es que no podemos obviar el hecho de que todas las instituciones jurídicas evolucionan, mutan y se adaptan a las necesidades de los nuevos tiempos, a la situación económica, política, cultural y a los adelantos tecnológicos; es un yerro considerar que las figuras jurídicas y las instituciones se mantienen indemnes, invariables, desconociendo que el derecho es tan sólo un reflejo de la realidad y, en especial, de la contratación, donde los negocios, los contratos y los formularios ayudan a formar la ley; como es sabido, el proceso es inverso: primero surgen los usos, las costumbres mercantiles y los negocios y luego se legisla, y no al revés. Es la metodología legislativa que se emplea en el ámbito del comercio y el derecho de la contratación.

Igualmente, cabe agregar en este sentido, el problema de la transnacionalización del derecho y de los trasplantes jurídicos de los países productores de derecho hacia los países receptores, así como de la mutua interdependencia entre las tradiciones jurídicas (Cfr. MERRYMAN, 1971); es decir, los países que adoptan instituciones foráneas para el desarrollo de sus negocios, contratos e inversiones (Cfr. BONILLA MALDONADO, 2009; SIERRRALTA y BAPTISTA, 1998).

Al adoptar figuras e instituciones jurídicas por la influencia del derecho de los países industrializados, se presentan problemas en la concepción, interpretación y aplicación de las figuras jurídicas. Desde esta perspectiva, la hermenéutica y la aplicación se dificultan para los jueces y tribunales locales. Empero, se parte de una falacia jurídica que es la que desdibuja per se el alcance y los efectos de la figura: su origen, pues realmente más que aplicar figuras jurídicas extrañas al sistema jurídico local, de raigambre continental europeo, lo más sensato es amoldar a las necesidades de los comerciantes las figuras e instituciones, amén 
de la asociación entre personas naturales y jurídicas para el desarrollo de proyectos y el posterior reparto de utilidades, es una actividad connatural al comercio y común a todos los sistemas jurídicos que subsisten en el siglo XXI.

Sea lo primero advertir, que en realidad el joint venture es una operación de negocios sumamente antigua, que no es exclusiva del derecho inglés o norteamericano y que, por ende, no se condice con los principios y la filosofía del derecho mercantil contemporáneo el pretender aplicar únicamente los postulados, rasgos y elementos del derecho anglosajón a la figura, sino que, por tratarse de una figura global, universal, lo más conveniente es aplicarla, ajustarla a la realidad local, con base en los lineamientos jurídicos que ofrece el derecho del civil law, no obstante la mutua interdependencia entre ambos sistemas jurídicos.

El mito consistente en que se trata de una figura eminentemente inglesa o norteamericana, sin referente en el derecho latinoamericano, ha conducido a graves problemas de aplicación e interpretación de la figura en negocios tan vitales para el sistema económico como el de telecomunicaciones, petróleos, minas, entre otros (Cfr. PARRA, 2004).

Es una figura jurídica de universal desarrollo, con orígenes comunes y a la que se deben aplicar regímenes y disposiciones legales claras, diáfanas, bien estructuradas, a fin de que los tribunales de arbitramento y los jueces locales no incurran en ambigüedades jurídicas que tan sólo benefician a los inversionistas extranjeros en detrimento de las empresas y la economía local.

Este aspecto histórico y, por ende, concepción y aplicación de la figura, condujeron a que, por ejemplo, en Colombia, no se entendiera el contexto y los elementos del joint venture $\mathrm{y}$, por consiguiente, se estipularan cláusulas inconvenientes, poco sanas y abusivas en la ejecución de negocios con compañías como Telecom, donde a costa de la inversión efectuada por el empresario extranjero, se pactó en el contrato joint venture, que por recaudo de 
facturación el Estado colombiano, percibiera el 10\% o $20 \%$ dependiendo de las condiciones finacieras estipuladas, manejadas incluso por regiones, lo cual fue objeto de debates de todo nivel, por ser considerado desfavorable y neonino, evidenciándolo cuando tuve la oportunidad de laborar en ella desde el año 1995 a 2003, cuando circunstacias políticas y económicas producto de la globalización, llevaron al Gobierno a ordenar el cierre definitivo de la misma.

Si la pretensión de unos inversionistas es asociarse, el Código de Comercio colombiano ofrece una gama muy amplia de posibilidades (cuentas en participación, sociedad comercial de hecho, sociedad anónima, en comandita, limitada, por acciones simplificada, colectiva), para la estructuración de cualquier plan de negocios sin que sea menester acudir a figuras extrañas a nuestro sistema jurídico que, en últimas tienen la misma finalidad, similar propósito pero con mejores garantías para la industria local y para los inversionistas y empresarios locales (Cfr. LÓPEZ GUZMÁN, 2002; CARO NIETO, 2005).

El problema del origen ha generado confusiones conceptuales que, más allá del dilema jurídico sobre su paternidad, en realidad se han traducido en problemas de aplicación, interpretación y limitación o extralimitación de responsabilidades en cabeza de los copartícipes. En palabras más simples: por el hecho de atribuirle a la figura jurídica objeto de estudio un origen exclusivamente anglosajón (inglés o norteamericano), se ha perdido de vista que se trata de una modalidad de negocios de asociación, con acentuados matices de las sociedades comerciales, y que para solucionar los vacíos y lagunas que existan en el negocio y en la interpretación de su clausulado, es viable y legítimo remitirse a las disposiciones que regulan el derecho de sociedades comerciales y el régimen de obligaciones y contratos previsto en los Códigos Civil y de Comercio, y además, que por el prurito de innovar o trasplantar figuras jurídicas en el ámbito de los negocios, es mejor recurrir al uso de figuras jurídicas en las cuales la ley, la doctrina y la jurisprudencia están suficientemente decantadas (Cfr. PEÑA NOSSA, 2014; ARRUBLA PAUCAR, 2005). 
Ello no ocurre con el joint venture, habida cuenta que se considera, entre otros aspectos, que es una modalidad de contratación atípica de origen puramente anglosajón, que suele confundirse con los consorcios y uniones temporales, y sobre el que no se cuenta con una regulación bien definida y delimitada, lo cual, como es sabido, conduce a litigios, pleitos e interpretaciones disímiles, que deben ser resueltos, por lo regular, ante tribunales de arbitraje comercial nacional e internacional.

Ya en lo que concierne a su evolución en el derecho colombiano, cabe añadir que esta clase de operaciones mercantiles son de reciente ocurrencia; fue a partir de la década de los años 90, con motivo de la internacionalización de la economía propuesta por la Constitución Política de 1991, que nuestro país abrió en definitiva las puertas a la inversión extranjera, y con ello surgieron las fusiones empresariales, las asociaciones de empresas y, por supuesto, las alianzas estratégicas y los joint ventures en Colombia.

Con la llegada de la inversión extranjera a nuestro país, se fortalecieron los negocios y la competitividad empresarial; por ende, se empezó a utilizar este tipo de figura jurídica en nuestro medio; no se tienen referencias empresariales o doctrinales sobre esta clase de operaciones mercantiles antes de la década de los años 90; fue a partir de este decenio, y en particular en los sectores minero, petrolero y de telecomunicaciones cuando se comenzó a aplicar la figura en nuestro país, con el propósito de permitir la participación extranjera en estas actividades económicas (Cfr. PARRA, 2004). La introducción de figuras como el consorcio y las uniones temporales en el artículo $7^{\circ}$ de la ley 80 de 1993 constituyen un ejemplo evidente de lo que aquí se afirma (OSORIO MORENO, 2008; OSORIO ARTURO, 1999). 


\section{FUNCIÓN ECONÓMICA DE LOS JOINT VENTURES}

Los joint ventures han sido catalogados como acuerdos bilaterales o multilaterales que se caracterizan por el compromiso de dos o más firmas asociadas, con objeto de realizar un proyecto en común y repartirse entre sí las utilidades al finalizar el negocio. Según la doctrina (MARZORATI, 1996; LE PERA, 1984), los joint ventures, por lo general, establecen una constelación de acuerdos que comprenden, entre otros aspectos, pactos sobre transferencia de tecnología, investigación y desarrollo conjuntos. En estos convenios se trata de introducir en la medida de los posible innovaciones tecnológicas, por ejemplo, joint ventures entre compañías de diferentes sectores de la industria, verbigracia, farmacéutico, automotriz, minero, petrolero, entre otros.

La doctrina internacional (SIERRALTA 1996; GUARDIOLA, 1998; LE PERA, 1984; MARZORATI, 1996; FARINA, 1999; PEÑA NOSSA, 2014; LÓPEZ GUZMÁN, 2005), coincide en sostener que la función económica de los joint ventures es muy variada, ya que ello depende del tipo de negocio, actividad, proyecto o tecnología que se va a explotar, no obstante que por lo general se organizan para disminuir riesgos y costes, ampliar el mercado, penetrar en economías regionales o a nivel global, transferir tecnología de punta, diversificar o fortificar la oferta de bienes y servicios.

Por consiguiente, una empresa, universidad, fundación u organización de cualquier naturaleza puede valerse del sistema de colaboración empresarial (joint venture), con objeto de adquirir tecnología y aprovechar el recurso humano para hacer feed back, esto es, hacer un proceso de retroalimentación permanente.

Los joint ventures son coaliciones formales entre dos o más organizaciones, que tienen como propósito esencial desarrollar empresas, proyectos o inversiones a 
corto, mediano o largo plazo, merced a las necesidades de los empresarios que las constituyen en el mercado o los negocios.

Las alianzas estratégicas o joint ventures se organizan bajo la modalidad de uniones de empresas, convenios empresariales de asociación, sociedades típicas 0 acuerdos formales. El tipo societario que los inversionistas pueden emplear es muy variado, y puede ir desde una sociedad anónima, una SAS (sociedad por acciones simplificada) ${ }^{10}$, sociedad de responsabilidad limitada, sociedad anónima europea, partnership, colectiva, en comandita, hasta modalidades de asociación diferentes para la ejecución de la operación de negocios de joint venture. Ello depende de los objetivos que se quieren cumplir, de la duración del proyecto, de la inversión, de las fortalezas y debilidades de cada uno de los tipos societarios, de las oportunidades de negocios, el grado de confianza y entendimiento de los partícipes, el sector económico, de los riesgos políticos y económicos e incluso del régimen de inversión extranjera en tratándose de contratos de joint venture internacional.

Los joint ventures han posibilitado la expansión de negocios a escala global, más que las adquisiciones y fusiones de empresas, ya que les han permitido a las compañías organizar establecimientos más allá de las regiones donde operan, sin arriesgar sus activos más importantes en virtud de la colaboración empresarial de otras firmas, disminuyendo así costos administrativos, laborales y financieros (Cfr. HILL, 2001; SIERRALTA, 1996).

\footnotetext{
10 "El tipo societario denominado sociedad por acciones simplificada SAS, se erige en una de las estructuras jurídico-empresariales más complejas de las sociedades por acciones y, por ende, del derecho corporativo contemporáneo, al igual que ocurre con el régimen de las sociedades extranjeras, las joint ventures internacionales y las sociedades anónimas. En la actualidad, las sociedades por acciones simplificadas, reguladas por la ley 1258 de 2008, dominan el escenario empresarial local, inciden en el desarrollo socio-económico de los países donde realizan sus actividades y juegan un papel preponderante en la inversión extranjera, la innovación tecnológica y el crecimiento del empleo (LÓPEZ GUZMÁN, 2012, pp. 15 - 16)
} 
Como es sabido por todos, la extensión de negocios a otras latitudes se lleva a cabo mediante diversos instrumentos jurídico-empresariales, verbigracia, la exportación de productos y servicios, la inversión extranjera y la instalación de filiales, satélites o subsidiarias en otros países.

Ahora bien, dadas las condiciones actuales de la aldea global, donde los riesgos políticos, las fluctuaciones económicas, el poder de mercado de algunas empresas, las nuevas tecnologías y las preferencias de los consumidores determinan las variaciones de la oferta y la demanda de bienes y servicios, las empresas han optado por el negocio de los joint ventures. La razón fundamental estriba en que mediante éstos se disminuyen los riesgos y costos de funcionamiento, se minimizan los problemas derivados de la comercialización, se comparten los riesgos financieros, se aportan innovaciones tecnológicas (patentes y know how), se incrementan los beneficios con la utilización de las ventajas comparativas y se obtienen efectos sinérgicos. Es decir, que con la participación de varias empresas para realizar cada función dentro de la operación de joint venture, se logran resultados económicos más satisfactorios, lo que simplemente puede expresarse con un antiguo adagio popular: la unión hace la fuerza (Cfr. COLAIÁCOVO y otros; SIERRALTA, 1996).

Lo anterior ha forzado a las empresas que desarrollan actividades en diversos países a unirse, aliarse, para buscar nuevos mercados, intercambiar información o conocimientos mediante licencias de patente y know how, licencias cruzadas entre empresas del mismo sector o de otro, compartir riesgos en la producción y distribución $y$, en general, para mejorar su rango competitivo en el mercado (Cfr. CABANELLAS, 1994).

Así se han organizado conglomerados económicos que laboran en distintos Estados, que producen a menores costos, con más eficiencia y calidad, respaldados por marcas de prestigio, conectados con los mejores equipos 
industriales y de comunicaciones. Igualmente, ello ha facilitado el abastecimiento simultáneo de las empresas que integran el contrato de joint venture.

Los joint venture se utilizan con frecuencia en la actualidad para transferir tecnología en diversos sectores (privado, público, internacional) de la economía y mejorar la productividad, así como los bienes y servicios que se ofrecen al consumidor. Igualmente, mediante este tipo de contratos atípicos el Estado fortalece la investigación en ciencia y tecnología. Como es sabido, estas actividades no se realizan por una sola persona jurídica, sino que, como es lógico, requieren la cooperación de entidades privadas, públicas e internacionales para poder llevarse a la práctica. Así, pues, mediante la asociación de diversas empresas y entidades (joint venture) se logran alcanzar los objetivos de avance en ciencia y tecnología propuestos por la Constitución Política de 1991. En el mismo sentido la doctrina nacional (SUÁREZ BELTRÁN, 2014, pp. 446 y 447):

Desde el punto de vista geográfico, los joint ventures han favorecido la integración regional, con el propósito de que los países vecinos formen nichos comerciales en beneficio de las economías que lo integran, verbigracia, las empresas binacionales argentino-brasileñas en el MERCOSUR, y lo que se pretendió con las EMAS (Empresas Multinacionales Andinas) en el ámbito de la CAN (Cfr. COLAIACOVO y otros, 1997; PARRA, 2005). Aunque vale la pena añadir que dichas estrategias de negocios nacionales e internacionales se han adosado con los procesos de integración económica global (el área de libre comercio, la unión aduanera, el mercado común, la unión económica y la unión política).

Por ello, la creación y organización de negocios de joint venture hace parte de los programas de integración, cooperación al desarrollo y de las políticas sobre promoción a la competitividad. Paralelamente, esto implica una armonización y unificación legislativa en lo comercial, lo tributario, en el régimen cambiario y de inversiones, así como en lo relativo a los mecanismos de solución de 
controversias (arbitraje comercial, amigable composición, conciliación, transacción, entre otros).

De todas maneras, si bien es cierto que la preexistencia de algún grado de integración económica no es requisito sine qua non para la constitución de empresas conjuntas (joint ventures) entre las compañías de países vecinos, lo cierto es que ello sí facilita las relaciones comerciales entre éstas $y$, por consiguiente, los aspectos relativos a trámites aduaneros, régimen cambiario y de inversión extranjera, por cuanto la legislación está unificada mediante tratados de libre comercio. El derecho de la Unión Europea es la mejor muestra de lo que se afirma, pues allí se promueven joint ventures para mejorar la competitividad en todos los sectores de la economía (Cfr. MANGAS MARTÍN y LIÑÁN NOGUERAS, 1999; DÍEZ HOCHLEITNER, 2001; MARTÍNEZ CAPDEVILA, 2000; GALINDO VACHA, 2002).

En resumen, la función económica de los joint ventures es muy amplia; sin embargo, puede afirmarse que, esencialmente, la finalidad de esta clase de operaciones y negocios mercantiles es potenciar la capacidad de las empresas que integran la empresa conjunta para desarrollar un proyecto en común, creando sinergias para mejorar la actividad comercial en que se desempeñan. Así mismo, se produce un proceso de benchmarking continuo en la actividad y en todo el conjunto de empresas que integran el joint venture, lo cual redunda en la imagen corporativa y en el proyecto mismo.

En todo caso, el recurso a este tipo de figuras jurídicas es útil para la ejecución de toda clase de proyectos y actividades a nivel nacional e internacional, no obstante la desconfianza que subsiste en el medio por el uso de esta clase de contratos, que se cree son nocivos para la industria nacional, dada su atipicidad contractual, así como la imposición de cláusulas abusivas y excesivamente onerosas por parte de las compañías multinacionales que contratan y se asocian con las empresas locales o con el Estado. La experiencia de Telecom y del sector petrolero en 
Colombia, constituyen una muestra fehaciente e irrefutable de lo que aquí se explica, amén de la problemática jurídica subyacente en las cláusulas de protección diplomática (cláusula calvo) y de renuncia a la jurisdicción aplicable al contrato (Cfr. REMIRO BROTÓNS, 1999; PARRA, 2005; BOGGIANO, 1985; IDROVO CUBIDES, 2005).

\section{EL JOINT VENTURE: DE CONTRATO “INTUIT PERSONAE" A CONTRATO “INTUITU INSTRUMENTI”.}

La doctrina nacional e internacional mayoritaria (PEÑA NOSSA, 2014; ARRUBLA PAUCAR, 2005; NAVÁEZ GARCÍA, 1990) ha considerado que los contratos de joint venture son intuitu personae, esto es, que se planifican y celebran teniendo en cuenta las calidades y características de los empresarios que van a integrar la empresa conjunta. Así, pues, si analizamos con detenimiento, vemos que uno de los aspectos fundamentales para realizar la asociación o empresa conjunta (joint venture) es verificar el perfil, la capacidad económica y las cualidades empresariales de los potenciales inversionistas, lo que se plasma en el plan de negocios (BORELLO, 2000).

La doctrina por lo común resalta, en lo relacionado con el punto, tres criterios: el cuantitativo (financiero) y cualitativo (empresarial) y la aptitud para el desarrollo del proyecto. El primero alude a la capacidad económica y financiera del empresarios o empresarios con los que se piensa realizar la operación de joint venture; es decir a la capacidad financiera que debe tener uno o varios de los potenciales asociados para el desarrollo del proyecto; el segundo, versa sobre las calidades personales de dichos empresarios, verbigracia, el espíritu empresarial, el liderazgo, la creatividad, la capacidad para solucionar problemas y situaciones críticas, entre otros. $Y$, el tercer punto, está referido a la aptitud para el desarrollo del proyecto, esto es, que el socio o inversionista elegido tenga las condiciones y la idoneidad para el proyecto específico que se pretende lleva a buen término. 
Así las cosas, el aspecto que, en principio, prima en la relación comercial, es la aptitud, el liderazgo y el hecho de poseer las calidades para la ejecución de un proyecto determinado. En otros términos, el elemento "intuitu personae" que, sin embargo, con el auge de la contratación en masa y la internacionalización de las relaciones comerciales, ha ido mutando hacia el denominado "intuitu instrumenti" (Cfr. RAVASSA, 2004; ORTUÑO BAEZA, 1997; CALVO CARAVACA y otros, 1997).

El carácter duradero de la relación surgida de los contratos de joint venture y las cualidades empresariales y financieras influyen en la elección de los empresarios con los que se pretende realizar la operación de joint venture. Los asociados no son ni más ni menos que los empresarios en quienes se confía para la realización de un negocio de joint venture. En este sentido se ha puesto de manifiesto la trascendencia del elemento confianza entre las partes en la relación creada por el contrato de joint venture $y$, en especial, por ser este aspecto el que más insiste la doctrina.

Dicho elemento (la confianza) es parte integral de las razones personales que sirven para tomar la decisión de asociarse con A y no con $\mathrm{B}$, y reviste particular interés en los contratos de joint venture internacional, pues, como es sabido, lo empresarios $y$, por ende, inversionistas no pueden actuar en contra de los intereses del proyecto y del acuerdo base del joint venture, ni realizar actos de competencia desleal con la información suministrada dentro del negocio de joint venture. En esta operación el principio de confianza se erige en piedra angular dentro del contrato.

La elección de los asociados, está, pues, íntimamente vinculada a la confianza y a la presunción de buena fe; sin dichos elementos el contrato no es posible. Asimismo, conviene agregar que la adecuada elección de los asociados inversionistas también está conectada a factores técnicos y humanos. Estos factores conforman el valor agregado de una empresa conjunta (joint venture) y 
repercuten en forma directa sobre el desarrollo y correcta ejecución del proyecto. En síntesis, las cualidades de los empresarios y la relación de confianza entre ellos tienen acentuada importancia en esta clase de relaciones contractuales (Cfr. SIERRALTA, 1996).

No obstante lo anterior, como se dijo al comienzo, la característica del "intuitu personae" se ha ido desplazando por la del "intuitu instrumenti", merced al hecho de que los empresarios, la contratación global y los requerimientos económicos del siglo XXI han ido despersonalizando las relaciones comerciales debido a que hoy predomina la contratación electrónica entre ausentes y los factores que se tienen en cuenta a la hora de contratar son objetivos y no subjetivos; es decir, se contrata y se efectúa la asociación o empresa conjunta (joint venture) en virtud del cumplimiento de unas condiciones objetivas, al margen de las consideraciones subjetivas y de los afectos y emociones subyacentes entre las partes (Cfr. RAVASSA, 2004). Prevalecen las características técnicas, comerciales, de solidez patrimonial, de prestigio y capacidad o aptitud para el desarrollo del proyecto que cualquier otra razón.

El comercio global y, por ende, la dinámica de los negocios en nuestro tiempo, le ha restado importancia a las cualidades personales, amén de que se ha eliminado el contacto personal y directo en las relaciones comerciales. En la moderna contratación y, por supuesto, en los contratos de joint venture, existe una tendencia hacia la despersonalización de los negocios y la empresa, ora por las dimensiones de ésta, verbigracia, compañías transnacionales que operan en casi todo el planeta, ora por el vertiginoso desarrollo de la empresa social (Cfr. GHERSI, 1992). Sin embargo, no podemos hablar de la extinción definitiva del "intuitu personae", pues éste seguirá haciendo presencia en contratos de colaboración empresarial de carácter nacional y de menor envergadura.

En definitiva, los nuevos contratos de joint venture son selectivos y no "intuitu personae", puesto que la contratación, la asociación entre empresas para la 
ejecución de proyectos en los distintos sectores económicos, básicamente no se realiza exclusivamente por la confianza entre las partes, sino con base en el cumplimiento de unos aspectos objetivos, como, por ejemplo, la experiencia en el área, el recurso humano, la capacidad tecnológica y financiera, la marca, el posicionamiento de la compañía, etc (Cfr. FARINA, 1999).

Por tanto, el contrato de joint venture es un contrato "selectivo", donde predomina el elemento "intuitu instrumenti", ya que si se estudia con detenimiento, se encentra que los socios venturistas o copartícipes contratan con base en el cumplimiento o satisfacción de unas condiciones o requisitos objetivos diseñados en el plan de negocios, contenidos en la ley y exigidos por los inversionistas para la ejecución del proyecto.

Si bien es cierto que el elemento confianza constituye la piedra angular sobre la cual se sustenta la relación comercial o de cooperación en el negocio de joint venture, a fase previa al desarrollo de la empresa conjunta, es decir, la etapa de selección, se realiza con elementos de juico objetivos, que atañen exclusivamente a los aspectos empresariales y de negocios. El elemento subjetivo (la persona natural o jurídica en sí misma considerada) no tiene nada que ver en la contratación contemporánea y en la empresa moderna. Además, no se trata de una postura caprichosa, sino que obedece a las nuevas tendencias de la contratación global, lo cual se infiere del análisis doctrinal, legislativo y jurisprudencial actual (Cfr. BARONA VILAR y otros).

\section{CREACIÓN Y ORGANIZACIÓN DE LOS JOINT VENTURES}

Todo negocio de joint venture requiere de una fase de formación o etapa previa a contrato. En este periodo se estudian y discuten las fortalezas y debilidades de la inversión y del proyecto que se pretende ejecutar mediante la operación conjunta de joint venture, se efectúan los acuerdos preliminares y se determina la participación, la modalidad, los montos y tipos de aportes que se van a realizar, en 
concomitancia con la duración el proyecto y los métodos alternativos de solución de conflictos.

Sin embargo, con el propósito de tener una idea más cercana de los que constituye una operación de joint venture y del desarrollo de este tipo de negocios a nivel nacional e internacional, es pertinente presentar una explicación de esta clase de inversiones para analizar aspectos problemáticos (Sobre inversiones nacionales e internacionales, cfr. CZINKOTA y RONKAINEN, 2002; IDROVO CUBIDES, 2002; DANIELS y RADEBAUGH, 2000).

a) INDIVIDUALIZACIÓN DE OPORTUNIDADES DE NEGOCIOS. Los comerciantes y los empresarios se dedican, esencialmente, a identificar las oportunidades de negocios a nivel global. El éxito comercial no es tan sólo resultado de la organización, la buena suerte, de un plan de mercadeo de los bienes y servicios que oferta la compañía, del buen desempeño de los trabajadores, del ahorro en los costes de producción, sino que, por el contrario, es la suma de todos ellos y de la identificación de oportunidades de negocios. Ello implica ab initio la identificación del negocio y de la zona geográfica donde se puede efectuar la inversión. Así, por ejemplo, en los negocios internacionales de joint venture, lo primero que se hace es realizar los estudios de mercadeo para determinar en qué negocios, sectores y países se puede invertir.

El éxito empresarial depende de las habilidades del buen hombre de negocios, de cómo conjuga éstas con su conocimiento, experiencia y tipo de negocio; aquí la visualización y la creatividad son factores clave para la identificación de oportunidades de negocio; en Colombia se adolece a nivel empresarial de un verdadero análisis económico del derecho que acompase las oportunidades de negocio. Igualmente, cae resaltar que todo ello implica la asunción de riesgos. 
Toda la actividad comercial está signada por el riesgo económico y está orientada a la consecución de buenas oportunidades, con el propósito de incrementar las utilidades, los beneficios, para expandirse y organizar nuevas filiales, subsidiarias o satélites y conquistar a más consumidores. En resumen, el elemento previo a la celebración de un acuerdo de joint venture es la individualización de oportunidades de negocios, lo que comporta un análisis paralelo de riesgos, utilidades y posibilidades de éxito; en otras palabras, el denominado due diligence, que en Colombia no se ha realizado juiciosamente en las operaciones de joint venture y ha causado problemas y litigios de diversa naturaleza (Caso Telecom).

b) ZONA DE NEGOCIOS. En lo tocante a la ubicación geográfica o zona de negocios donde se puede efectuar la inversión, es indudable que los empresarios y los hombres de negocios no solo identifican la oportunidad de negocios sino el lugar donde ello se puede materializar.

En la nueva sociedad informatizada del siglo XXI, los empresarios buscan y encuentran oportunidades de negocios en muchas zonas geográficas, donde las condiciones culturales, políticas, económicas y sociales son bien distintas. Por ello, se afirma que el capital, los negocios y las inversiones son un asunto global y no exclusivamente local. Así las cosas, las oportunidades de negocios son dispares en todo el orbe y dependen en buena parte del desarrollo tecnológico de una región, país o bloque económico, de la cultura, de la situación económica y financiera, de la flexibilidad del régimen de inversión extranjera y de la estructura legal en materias laboral, tributaria y comercial (Cfr. HILL, 2001).

La falta de éxito de muchas empresas conjuntas en Colombia se ha debido a este factor; no se trata de invertir por obtener utilidades, sino de hacerlo en forma consciente y en beneficio no sólo de las compañías implicadas en el negocio de joint venture, sino también de la colectividad (Empresas sociales. Cfr. YUNUS; STIGLITZ, 2002). De todas maneras, por ello en los 
negocios internacionales de joint venture se analizan también los factores culturales y geográficos, jurídicos, económicos, es decir, las condiciones locales, puesto que un sistema de negocios no puede ser exitoso en todas las zonas geográficas del orbe. No los modelos de negocios, ni las estrategias ni las inversiones pueden ser homogéneas.

Las inversiones y los negocios de joint venture están sujetos al régimen financiero, cambiario y de inversiones de cada país. En lo tocante a la modalidad de inversión extranjera, es menester precisar lo siguiente:

La inversión puede ser directa, en cuyo caso los aportes de capital de una compañía o de varias compañías que integran el joint venture, se pueden efectuar mediante contratos, participaciones, acciones o cuotas adquiridas con vocación de permanencia. La inversión es en portafolio cuando se efectúa en títulos valores, en el mercado bursátil. Este tipo de inversiones han sido sumamente criticadas porque en su mayor parte benefician tan sólo a los empresarios inversionistas y no a la economía local; se conocen con el nombre de capitales golondrinas; de ahí que se han impuesto restricciones legales y exigencias a este tipo de inversiones en el marco de las joint ventures (Estatuto de inversiones en Colombia) (Cfr. IDROVO CUBIDES, 2005; Cfr. OTIS-RODNER, 1993).

c) EXPLORACIÓN DE LOS POTENCIALES INVERSIONISTAS. En los contratos y operaciones mercantiles de joint venture, se debe examinar con suma atención con quién o quiénes se a realizar la alianza estratégica. Esto es, si se trata de compañías multinacionales, privadas, públicas, cooperativas, de qué sector económico son, qué experiencia tienen, si son consorcios, uniones temporales, si están excluidos de la lista Clinton, o si, entre otros aspectos, alguno de los asociados intenta realizar operaciones de blanqueo de capitales mediante la asociación a riesgo compartido o joint venture.

d) ETAPA DE ACUERDOS PREVIOS. Las negociaciones preliminares para realizar el acuerdo de joint venture exigen estudios previos y examen de los 
sistemas jurídicos a los cuales pertenecen los potenciales socios o inversionistas. Se envían las propuestas de negocios mediante correo electrónico (ley 527 de 1999; Convención sobre Comunicaciones Electrónicas en Contratos Internacionales de la CNUDMI), se plantean los formularios de contratación sobre joint venture, y aquí en este juego de ofertas y contraofertas es donde se presentan los inconvenientes por la batalla de los formularios a que hace referencia la doctrina internacional (PERALES VISCASILLAS, 1996). Así surge o se forma el contrato internacional de joint venture y desde esta fase preliminar se presentan obligaciones y responsabilidades para las partes, verbigracia, de confidencialidad de la información suministrada por los socios potenciales.

e) OBJETO DE LA INVERSIÓN. Las alianzas estratégicas se constituyen con los propósitos más variados, como, por ejemplo, invertir en mercados externos, publicidad, cine, televisión, sectores minero y petrolero, medio ambiente o empresas de interés social. El objeto social es sumamente amplio y abarca todos los sectores de la economía. Si se constituye una sociedad mercantil como vehículo de inversión y operaciones de la empresa conjunta de joint venture, por lo regular el objeto social debe ser determinado, excepto si se trata de una SAS, ya que la ley 1258 de 2008 admite la constitución de este tipo de compañías con objeto social indeterminado, al igual que en la legislación de los Estados Unidos y Panamá.

En otros términos, se pueden organizar joint ventures con objeto social indeterminado, permitiendo que se realicen toda clase de operaciones y negocios lícitos, y no es menester que para que el joint venture sea legal o se pueda permitir su actuación en el mercado interno, su objeto social deba estar precisamente determinado en el contrato o en la sociedad comercial escogida por los inversionistas (Sobre el objeto social, cfr. GIL ECHEVERRY, 2012). 
f) LEGISLACIÓN APLICABLE. Dentro de los aspectos más relevantes que se deben tener en cuenta a la hora de estructurar un negocio mercantil de joint venture está el relacionado con la legislación aplicable al contrato. No es un problema menor y de poca monta, ya que cada una de las partes que participa en el proyecto está interesada en aplicar la legislación de su propio Estado porque la considera más viable, más apropiada para el negocio, la conoce y tiene por lo común conexiones con los tribunales locales.

Lo más adecuado para este tipo de operaciones mercantiles es estipular una legislación internacional, someter el contrato a algún convenio internacional de cooperación, o en definitiva, convenir con los socios el sometimiento a un ordenamiento jurídico específico beneficioso para todas las partes, que ofrezca seguridad y solidez jurídica, de tradición y que sus tribunales se caractericen por obrar y decidir con honradez y rectitud, incluso es mejor un tribunal de arbitramento internacional sometido, verbigracia, al Reglamento de 1998 de la CCI sobre arbitraje comercial (Cfr. DERAINS y SCHWARTZ, 2001).

g) TIEMPO DE LA INVERSIÓN. Es la duración del proyecto, o sea, el plazo en que se va a ejecutar la operación conjunta de joint venture. Las partes están obligadas a fijar de antemano las condiciones del negocio y, en particular, el tiempo en que se va a desarrollar el proyecto específico, para disponer de los recursos económicos, financieros, técnicos y humanos para poner en funcionamiento la obra conjunta.

A contrario sensu, si estos aspectos no están precisamente especificados en el proyecto de inversión, se pueden presentar conflictos entre las partes. La duración está limitada al término del proyecto; si los copartícipes del joint venture emplean una sociedad mercantil como vehículo de inversión del negocio, se debe estipular un término de duración de la compañía, el cual está íntimamente vinculado al proyecto, excepto, claro está, como se ha 
indicado con anterioridad, si los socios constituyen una SAS, dado que el término también puede ser indefinido (Cfr. LÓPEZ GUZMÁN, 2012; REYES VILLAMIZAR, 2013). En todo caso, lo cierto es que el término de duración depende del negocio o proyecto que van a ejecutar los socios venturistas.

PETER F. DRUCKER (2002) plantea cinco elementos de vital importancia para que los joint ventures sean exitosos, y dentro de ellos menciona los de orden jurídico, económico, financiero, cultural, político y empresarial. Al respecto explica lo siguiente:

1) Previo a la suscripción de una alianza estratégica o contrato de joint venture, los socios venturistas deben fijar sus objetivos; con frecuencia, cuando una joint venture ha dado buenos resultados, se hace evidente que las metas conjuntas y los propósitos individuales de los inversionistas sean compatibles.

2) Es fundamental lograr un acuerdo previo acerca de cómo se administra la alianza estratégica. ¿Se deben reinvertir las utilidades o se deben enviar a las casas matrices a la mayor brevedad posible? ¿Debe desarrollar la empresa su propia investigación o se debe contratar exclusivamente a una o ambas compañías matrices? ¿Con qué nombres se patentarán los resultados, con el de la institución que proporciona capital humano e instalaciones, o con el de la compañía que paga la cuenta? Todo esto indica que es necesario pensar cuidadosamente acerca de la administración del joint venture; sin tener en cuenta asimismo la forma específica que se asuma, debe ser gestionada independientemente y el personal que está a cargo debe gozar de los incentivos suficientes para alcanzar las metas y objetivos propuestos.

3) Es imperativo establecer quién dirigirá la operación conjunta de joint venture, al margen de la estructura legal, debe ser gestionada por uno de los socios que participan en el proyecto y no por una compañía o persona natural externa; es inconveniente hacerlo por conducto de un comité, y 
debe quedar claro desde el comienzo que las personas que administran el joint venture se miden por su rendimiento y por los resultados que se obtengan con el negocio.

4) Cada socio debe tomar medidas dentro de su propia estructura para asegurar que las relaciones sean fluidas con la empresa conjunta de joint venture y los socios. El personal de gerencia debe tener acceso a alguna organización matriz que pueda tomar determinaciones, sin que sea menester realizar mayores trámites burocráticos.

5) Los socios deben llegar a acuerdos para resolver las controversias o conflictos que van surgiendo durante la relación comercial. Esto por lo común se hace por intermedio de un árbitro, conciliador o mediador externo al que ambas partes le confieren facultades para tomar decisiones sobre el conflicto y cuyo veredicto sea aceptado como definitivo entre los asociados.

De lo manifestado hasta ahora se puede inferir que la constitución de joint ventures y alianzas estratégicas es una excelente alternativa de negocios para empresarios y comerciantes pertenecientes a economías emergentes (Cfr. OHMAE, 2005). Los joint ventures son la solución a muchos problemas y obstáculos financieros, económicos y tecnológicos que deben afrontar las compañías de los países en vía de desarrollo. La cuestión es que las alianzas estratégicas y los joint ventures han transformado y continuarán trasfigurando la manera como se hace negocios en los distintos sectores económicos. 


\section{CAPÍTULO II}

\section{DE LA FORMACIÓN DEL CONTRATO DE JOINT VENTURE}

\section{INTRODUCCIÓN}

Estudiados los aspectos preliminares en el contrato de joint venture, se procede enseguida al análisis jurídico de la formación del contrato. Agotados los primeros contactos entre los potenciales socios de la asociación o empresa conjunta, el siguiente paso para la formalización del negocio u operación de joint venture son los tratos preliminares; dicha fase concluye con la oferta y respectiva aceptación por parte de los futuros asociados, lo cual depende del cumplimiento de unos requisitos objetivos y subjetivos de contratación, verbigracia, la experiencia, el poseer tecnología de punta, capacidad financiera y recursos humano altamente cualificado, entre otros.

Luego se discute acerca de los puntos básicos de la alianza estratégica, a saber: los aportes en especie y en dinero o propiedad intelectual que se van a incluir en la operación de joint venture, el órgano de control y administración de la joint venture, el proyecto que se va a ejecutar, el término de duración, etc.

En la fase preliminar no se analizan los pormenores jurídicos del contrato, sino que, además, se analizan los aspectos concernientes al perfil de los socios que van a integrar el proyecto, su capacidad económica, su experiencia empresarial, su conocimiento del sector donde se va a realizar el proyecto, entre otros aspectos. En otros términos, la negociación preliminar en el contrato de joint venture no se constriñe al estudio del proyecto o al análisis de los socios sino también a la oferta y aceptación que hagan los potenciales socios de la operación conjunta, amén de aspectos extrajurídicos como el económico, el financiero, el 
cultural, el político y social de la región donde se va a llevar a cabo el proyecto (Cfr. PAULEAU, 2003; PARRA, 2004).

Lo primero es la búsqueda de los socios ideales para el desarrollo del negocio de joint venture. Definido el socio o socios que van a conformar la operación conjunta, se empiezan a realizar los tratos preliminares para la formalización del contrato de joint venture a nivel nacional o internacional. Respecto de los requisitos del socio ideal en los contratos de joint venture, indica la doctrina (ECHARRI, PENDÁS y DE QUINTANA, 2002, pp. $33-34)$ :

"La búsqueda de un socio apropiado es esencial para el éxito de la joint venture. Además de las negociaciones y redacción de documentos legales y operacionales, hay que emplear una importante cantidad de tiempo y, a veces, de dinero, identificando y analizando a los posibles candidatos. El socio adecuado para una joint venture es aquél que tiene una serie de capacidades complementarias y que puede trabajar de forma efectiva con la compañía de uno mismo. Esta complementariedad tiene dos aspectos fundamentales: el técnico y el organizativo.

"En lo que al complemento técnico se refiere, lo primero que hay que valorar son los conocimientos o recursos que el socio ideal debería tener; para ello conviene responder a las siguientes preguntas: ¿Qué conocimientos o recursos necesita la joint venture? ¿Cuáles de los anteriores ya tengo y en qué medida? De aquellos que no tengo, ¿cuáles son los más importantes? ¿Cuáles de los anteriores podría adquirir de otra manera que no se a través de una joint venture?

"En este mismo sentido, también es muy importante seleccionar a un socio que tenga capacidad financiera suficiente para inyectar capital mantener la joint venture. Para ello, habrá que revisar los estados contables, verificar si 
es una compañía sólida desde el punto de vista financiero, comprobar la política de crecimiento e inversión e los resultados, etc.

"Respecto del complemento organizativo, la compatibilidad afecta a cómo de bien van a cooperar las partes. Si no existe ninguna cooperación, lo único que se conseguirá es incrementar los costes y consecuentemente los conflictos y compromisos.

El grado de cooperación suele incrementarse en relación con el nivel de complejidad e inseguridad de la joint venture, que a su vez suele incrementarse en relación con el aumento de sus funciones (investigación, diseño, fabricación, marketing y distribución), productos y mercados, así como en función del incremento de los objetivos estratégicos y falta de similitud de los socios.

"Otro asunto muy importante a tener en cuenta a la hora de formalizar un acuerdo de joint venture es la diferencia de tamaño entre las compañías, lo que obliga a realizar ajustes específicos para minimizar tales diferencias, por ejemplo, dándole a la joint venture suficiente autonomía.

"No se puede perder de vista el hecho de que cada compañía es única. Su estructura y sus prácticas comerciales están normalmente adaptadas en función de la cultura del país al que pertenecen, la normativa vigente, la propia historia de la empresa, la personalidad de sus fundadores y la actitud de sus directivos. Por ello es importante emplear todo el tiempo que se considere necesario hasta comprender las diferencias con el posible socio, y entonces tratar de desarrollar durante las negociaciones la manera de enfrentarse a las mismas. En este sentido, conviene comprobar lo siguiente:

"Si las estructuras operativas y directivas son centralizadas 0 descentralizadas. La estructura organizativa (matriz, departamentos 
internacionales, etc.). Estrategias de marketing y de distribución, política y filosofía de servicio al cliente. Fortaleza financiera, diversificación de riesgos, política de dividendos, reinversión, resultados financieros, política de impuestos, etc. Clase de sociedad (familiar, cotizada, pública). Política laboral (indemnizaciones, estrategia a la hora de contratar). Relaciones laborales (existencia de representantes de los trabajadores o no, revisión de la situación de los empleados, etc.)".

\section{FORMACIÓN DEL CONTRATO DE JOINT VENTURE Y DE LA ALIANZA ESTRATÉGICA}

\subsection{EL PROBLEMA DE LA OFERTA EN EL JOINT VENTURE}

El marco regulatorio de la oferta en el contrato de joint venture es diferente en cada país, su aceptación, revocación y caducidad, es distinta en cada legislación. Igualmente, cabe resaltar que existen algunas normas internacionales en materia de oferta y aceptación que se pueden aplicar a otros contratos, como, por ejemplo, los contratos de joint venture; se trata de la Convención de Viena de 1980 sobre los contratos de compraventa internacional de mercaderías y los Principios Unidroit, cuya última versión es de 2010.

En Colombia la oferta está regulada en los artículos 845 a 860 del Código de Comercio colombiano, y la oferta por internet está reglamentada en la ley 527 de 1999. Sea lo primero aludir a la normativa interna sobre oferta y aceptación, esto es, sobre la formación del contrato de joint venture:

Al margen del hecho de que el negocio de joint venture sea contractual o corporativo - joint venture contractual o joint venture corporation -, esta operación mercantil nace a la vida jurídica, surge mediante un contrato o negocio jurídico donde las partes exteriorizan su voluntad de formar y ejecutar el contrato, de contraer obligaciones. Ciertamente, el artículo 845 del Código de Comercio 
colombiano, estipula que la oferta de contratar se presenta cuando uno de los posibles socios manifiesta su ánimo, su propósito de formar una joint venture y lo comunica por cualquier medio físico o virtual, léase oferta mediante documento o por intermedio de mensaje de datos, conforme a la ley 527 de 1999 (Cfr. RAVASSA, 2004; PEÑA NOSSA, 2014).

Se entiende comunicada la oferta de contrato de joint venture cuando ha sido comunicada al destinatario o destinatarios (posibles socios). Según el artículo 846 el Código de Comercio, la oferta es irrevocable, pero si se revoca se deben indemnizar los daños y perjuicios que se hayan causado.

Lo primero que hay que destacar aquí, es que la norma no contempla la posibilidad de que el incumplido sea constreñido al cumplimiento del contrato, al cumplimiento de la oferta, porque es factible que los potenciales socios que aceptaron la oferta y a los que les fue revocada por el proponente, no estén interesados en recibir la indemnización de perjuicios, sino en ejecutar el contrato, en cuyo caso pueden solicitarle al juez 0 al tribunal de arbitramento que se obligue a la parte incumplida a cumplir integralmente con la oferta que envió como sustituto de la indemnización de perjuicios (daño emergente y lucro cesante).

Es una alternativa que la norma no contempla, no prevé, pero que sí está contenida en la Convención de Naciones Unidas sobre compraventa internacional de mercaderías, aprobada en Colombia por intermedio de la ley 518 de 1999, y que puede ser aplicada en el ordenamiento jurídico interno por analogía, conforme lo expone la doctrina en opinión que compartimos plenamente (Cfr. OVIEDO ALBÁN, 2008).

Así mismo, la oferta realizada por el socio potencial del negocio de joint venture conserva su carácter obligatorio aunque el proponente muera o llegue a ser incapaz en el tiempo medio entre la expedición de la oferta y su aceptación, 
excepto que de la naturaleza de la oferta o de la voluntad del proponente e infiera una intención distinta.

\subsection{LA OFERTA O PROPUESTA VERBAL EN EL JOINT VENTURE}

En los contratos de joint venture a nivel nacional, la propuesta u oferta verbal entre presentes deberá ser aceptada o rechazada en el acto de oírse. No obstante lo anterior, también puede ser aceptada por conducto de representante, mandatario o apoderado, siempre y cuando el apoderado o mandatario tenga poder y facultades para hacerlo; de lo contrario, éste actúa ultra vires, y en dado caso su aceptación no obliga al destinatario, a los socios potenciales que supuestamente aceptaron la oferta de contratar para constituir un negocio de joint venture.

Sin embargo, en otras legislaciones como la de los Estados Unidos, las actuaciones ultra vires de los administradores y representantes obligan a la sociedad (Cfr. REYES VILLAMIZAR, 2006; PEÑA NOSSA, 2014); en esta hipótesis, la extralimitación del administrador o representante legal obliga a que éste deba indemnizar los daños y perjuicios que pueda ocasionar a los socios y a terceros, o sea, la relación de confianza entre éste y los socios de la compañía que representa impone deberes objetivos de cumplimiento y la responsabilidad es objetiva; ante terceros responde la sociedad en aras de proteger el tráfico jurídico mercantil (Cfr. RAVASSA MORENO, 2004).

\subsection{LA OFERTA POR ESCRITO EN EL JOINT VENTURE}

En la legislación nacional, cuando la oferta de contratación interna de joint venture se hace por escrito, deberá ser aceptada o rechazada dentro de los seis días siguientes a la fecha en que tenga la propuesta, si el destinatario reside en el mismo lugar del proponente; si reside en lugar distinto, a dicho término se sumará el de la distancia. 
Lo anterior conforme a lo previsto por el artículo 851 del estatuto mercantil colombiano. Aquí, el término previsto en la ley tenía sentido en la época en que se expidió el Código de Comercio colombiano, habida cuenta porque no se disponía de los recursos tecnológicos y técnicos con que se cuenta hoy en el siglo XXI, y por ello el término resultaba pertinente, conveniente, racional y adecuado.

Hoy, por el contrario, merced al uso del internet y las nuevas tecnologías, el plazo de los seis días es muy amplio, extenso (Sobre la contratación electrónica en el siglo XXI y los problemas que aquí se abordan, cfr. JULIÁ BARCELÓ, 2000). Entre tanto, la norma no hace referencia al hecho de que el lugar de residencia sea en el mismo país, en la misma plaza (ciudad) o región.

En la nueva era de la globalización de los mercados y la producción, donde lo corriente es la contratación internacional y entre ausentes, los negocios de joint venture se efectúan entre empresarios de distintos países, y no se sabe ni se lograr inferir si la norma (C. de Co., art. 851) alude a un lugar en el mismo país, en la misma plaza, o es muy amplia y también abarca aquellas hipótesis en las cuales el destinatario reside en otro país, en cuyo caso se trata de una disposición con efectos en el comercio internacional, pero que resulta vaga e insuficiente para las necesidades del comercio del siglo XXI.

En el fondo esta parte de la norma es una norma de conflicto, visto desde la perspectiva del derecho internacional privado, o sea una norma que determina el foro aplicable al contrato internacional de joint venture. $Y$ el inconveniente también es que el término de la distancia es un concepto muy ambiguo, porque el término de la distancia si lo medimos con base en los medios tecnológicos es inmediato, un mensaje de texto, un correo electrónico es inmediato, no requiere horas, ni días. Si el término de la distancia lo medimos con base en el transporte aéreo o marítimo la situación es bien distinta; de manera que la norma, tal y como está redactada es incompleta, insuficiente y ambigua respecto de los requerimientos del comercio y la contratación contemporánea (Sobre la contratación 
contemporánea y sus vicisitudes, cfr. CALVO CARAVACA y otros, 1997; FERNÁNDEZ DE LA GÁNDARA, 1995; OVIEDO ALBÁN, 2004).

No obstante que de acuerdo con el artículo 852 del estatuto mercantil colombiano el término de la distancia depende el medio de comunicación empleado, el primer escollo es el concerniente a la unificación del medio que se debe utilizar, y si se utilizan varios cuál es el que se debe tener en cuenta, ¿El más rápido? ¿El primero, o el último? ¿Uno o varios? ¿Se suman y promedian todos los términos? La solución que ofrece la legislación colombiana es, sin duda, nicho de litigios y de diferentes interpretaciones jurídicas.

\subsection{LOS PLAZOS Y LA ACEPTACIÓN DE LA OFERTA EN EL JOINT VENTURE}

En lo concerniente a la estipulación de los plazos el artículo 853 del Código de Comercio colombiano, conviene agregar que es un vivo desarrollo del postulado de la autonomía de la voluntad, y específicamente, del principio de autonomía material mediante el cual en un contrato de joint venture internacional se le permite a las partes escoger las condiciones y la forma del contrato, al igual que en todo contrato internacional (Cfr. BARONA VILAR y otros, 1999). Pero esa fijación de los plazos implica que las partes, es decir, los socios potenciales ya han adelantado un importante trecho de la negociación de la empresa conjunta.

En lo tocante a la aceptación tácita, se siguen en este punto las mismas reglas de la contratación global (comparada e internacional), dado que la presunción referida forma el contrato y obliga a las partes. Empero, ello exige seguridad, certeza plena de que el destinatario ha aceptado y, por ende, se puede constituir el contrato de joint venture; de lo contrario, es un punto de la negociación que causará litigios y diversas controversias entre las partes, y las partes deberán designar un tribunal de arbitramento o acudir a las instancias judiciales para resolver la controversia. 
En el primer caso mediante un pacto arbitral (cláusula compromisoria o compromiso), y en el segundo, instaurando las acciones judiciales internas a que haya lugar (Sobre conflictos entre asociados y su solución mediante arbitraje, cfr. GIL ECHEVERRY, 2013; CORREA ARANGO, 2013; LÓPEZ BLANCO, 2013).

En los supuestos donde la aceptación de formar la joint venture sea extemporánea o condicional, la disposición (C. de Co., art. 855) estatuye que se considerará una nueva propuesta. Sin embargo, nada obsta para que las partes mantengan las condiciones iniciales señaladas en la oferta y materialicen el contrato de joint venture con un anexo o adenda, o con una cláusula de otro sí al negocio u oferta mercantil original.

De todas maneras el incumplimiento, incluso en esta fase preliminar, obliga a que la parte incumplida, la parte que causó daños y perjuicios deba indemnizar a la parte afectada (léase daño emergente y lucro cesante) (Cfr. ARRUBLA PAUCAR, 2005; PEÑA NOSSA, 2014). Sin embargo, nada se dice en el ordenamiento jurídico interno sobre la posibilidad de cobrar o exigir perjuicios morales; ciertamente en la doctrina, en la jurisprudencia y en la legislación comparada ha hecho carrera la tesis según la cual es factible exigir el perjuicio moral por el incumplimiento contractual; se trata de una tesis novedosa, interesante que vale la pena tener en cuenta en el marco del ordenamiento jurídico colombiano y que en el contexto de los contratos de joint venture se puede aplicar con base en los principios generales de obligaciones y contratos mercantiles.

\subsection{LA REVOCACIÓN DE LA OFERTA EN LOS JOINT VENTURE}

En lo tocante a la revocación de la oferta pública, se aplican los criterios indicados en el artículo 857 del Código de Comercio colombiano. La disposición comentada exige justa causa para la revocatoria de la oferta, e impone que la revocación 
debe hacerse en la misma forma en que se puso en conocimiento al público la oferta respectiva. Así las cosas, para un negocio de joint venture en el que se hace una oferta pública, la revocación de ésta, se debe realizar por una justa causa y en las mismas condiciones en que se hizo la oferta inicial.

Justa causa en el marco de un contrato de joint venture sería el cambio abrupto en las condiciones económicas donde se va a efectuar la inversión; el hallarse en incurso en las condiciones y requisitos de la quiebra o estado de insolvencia empresarial (Cfr. Ley 1116 de 2006; LÓPEZ GUZMÁN, 2007; RODRÍGUEZ ESPITIA, 2006); la expropiación de la compañía o la extinción de dominio del capital de la sociedad y la correspondiente cancelación de la personería jurídica de la empresa que se pretende asociar, entre muchos otros aspectos y posibles causas justas de revocatoria de la oferta pública de contratación del joint venture.

Aunque lo que ocurre es que esas justas causas también están vinculadas a la legislación del país donde funciona la empresa, pues las justificaciones legales o las causales que constituyen eximentes de responsabilidad contractual difieren en el ordenamiento jurídico comparado.

En tratándose de varias personas, conforme a lo señalado por el artículo 858 del Código de Comercio, estará obligada al cumplimiento de lo propuesto en la oferta el potencial socio que primero hizo la oferta o de quien el oferente en principio reciba aviso de su cumplimiento. Sin embargo, por ser un contrato de cooperación o colaboración empresarial, lo más lógico sería que se cumplieran todas las propuestas contenidas en las ofertas efectuadas por todos los potenciales socios de la joint venture.

Entre tanto, es pertinente acotar que el oferente del contrato de joint venture no podrá utilizar las obras ejecutadas por las personas naturales o jurídicas excluidas de la prestación ofrecida. Si lo hiciere, deberá asimismo indemnizar los daños y perjuicios que cause. 


\subsection{LA OFERTA Y LA CONFIDENCIALIDAD DE INFORMACIÓN E INNIOVACIONES TECNOLÓGICAS EN LOS JOINT ENTURES}

En la etapa preliminar de formación del contrato de joint venture, las partes tienen el deber de confidencialidad o de secreto sobre la información o know how que les sea revelado. Si no se respeta esa informaci'n confidencial, la parte incumplida deberá indemnizar los daños y perjuicios que se causen con dicha conducta.

El hecho de revelar información confidencial obliga a indemnizar los perjuicios que con la conducta se cause a las compañías vinculadas en esta fase previa de la operación conjunta, aparte de que se erige en una típica conducta de competencia desleal, de acuerdo a lo previsto por la ley 256 de 1996. Por ello, los posibles socios suscriben por lo regular un convenio de confidencialidad en esta fase preliminar del contrato de joint venture (Cfr. PAULEAU, 2003).

En efecto, al respecto indica la doctrina (ECHARRI, PENDÁS y DE QUINTANA, 2002, p. 27):

"Teniendo en cuenta que desde un primer momento los posibles socios van a intercambiar información de carácter confidencial, parece lógico formalizar un acuerdo en el que se definan, al menos, los siguientes aspectos: Qué se entiende por información confidencial. Cómo se identifica dicha información. Cuáles son los fines para los que se entrega la información confidencial. Durante qué periodo de tiempo debe mantenerse la información como confidencial y bajo qué circunstancias perderá dicho carácter. Consecuencias del incumplimiento (indemnizaciones). Cláusula de exclusividad. Asimismo, se pueden incluir las llamadas cláusulas Chinese Walls, en virtud de las cuales las partes se comprometen a no contratar durante un cierto período de tiempo a ningún miembro el equipo de la otra parte que haya tenido acceso a la información confidencial. Mediante la 
firma de este tipo de acuerdos, se evitarán numerosas consecuencias perjudiciales para las partes en caso de que se produjera la ruptura de las negociaciones".

El empresario o empresarios revelan en la etapa precontractual parte el secreto empresarial o know how a los demás inversionistas para la realización del proyecto. Si bien es cierto que en la información preliminar se les suministra a los potenciales socios del joint venture parte de la información, dicha revelación, aunque fragmentaria, constituye de todas maneras un riesgo para el empresario o empresarios que lo hacen, se expone a que sus competidores aprovechan y absorban toda la información tecnológica (patentes y know how) y luego exploten en su propio beneficio dicha información tecnológica y, a su vez, confidencial de la empresa, su ventaja competitiva (Cfr. PORTER, 2006).

Ante el valor capital que tienen las patentes y el know how, los procedimientos y conocimientos técnicos de las compañías, en conjunción con la marca, el goodwill empresarial, etc., lo más aconsejable es que el potencial socio le solicite a los demás inversionistas la suscripción de un acuerdo de confidencialidad en esta fase preliminar, con el propósito de evitar actos de competencia desleal, contrarios a la ética empresarial, que puedan causarle serios daños patrimoniales a la empresa que quiere asociarse en un negocio de colaboración como el de joint venture (Cfr. LÓPEZ GUZMÁN, 2002; STUMPF, 1984; MARZORATI, 1996).

De hecho, el artículo 6 de la ley 256 de 1996 sobre competencia desleal establece que se considera desleal la divulgación o explotación, sin autorización de su titular, de secretos empresariales e información confidencial a la que se haya tenido acceso legítimamente pero con el deber de reserva, o ilegítimamente, a consecuencia de algunas de las conductas señaladas en el artículo 18 del mismo ordenamiento mencionado. En idénticos términos se pronuncia la legislación española que sirvió de referente y apoyo a la ley colombiana sobre competencia desleal en el artículo 13 de la ley de 3 de enero de 1991. 


\subsection{EL PROBLEMA DE LA VALORACIÓN DE INTANGIBLES EN LA OFERTA DEL JOINT VENTURE}

Otra disposición que también se refiere al punto que venimos comentado, es el artículo 265 de la Decisión 486 de 2000 de la Comunidad Andina, que regula todo lo atinente a la propiedad industrial y a los contratos que se pueden realizar con ésta para transferir tecnología, y dentro de éstos, cabe igualmente el negocio de joint venture mediante la licencia de patente y know how (Cfr. RAVASSA MORENO, 2001, T. I, 2001; METKE MÉNDEZ, 2001; ASCARELLI, 1970).

El problema con estas contribuciones tecnológicas es el tratamiento jurídico que le otorga la legislación nacional, las diferencias conceptuales que allí se presentan y la forma en que este tipo de aportes empresariales se contabilizan dentro de una joint venture, sobre todo en la etapa preliminar del contrato. No sólo surgen algunos valladares jurídicos y económicos por la prohibición de competencia en esta fase preliminar del contrato, o sea, en la etapa pre formativa, sino también cómo valoramos, cuantificamos este tipo de aportes (patentes y know how), y si éstos son aportes en especie o en industria. Depende de cómo se cuantifique valore financieramente esta clase de aporte o contribución patrimonial y qué clase de aporte lo consideran los posibles socios, porque la regulación es diferente. Desde el comienzo es un punto sobre el cual los socios deben dejar todo dilucidado (Al respecto, Cfr. LÓPEZ GUZMÁN, 2002; NARVÁEZ GARCÍA, 1998; PACHÓN y SÁNCHEZ, 1995; STUMPF, 1984).

Si en la etapa formativa del contrato se considera un aporte en industria, a la compañía que hace la contribución tecnológica se le paga como a un socio industrial, con y sin estimación de su valor; por el contrario, si se considera un aporte en especie, verbigracia, la legislación europea, el pago y las utilidades al socio inversionista el similar, es igual al que se le hace a un socio que aportó dinero en efectivo o bienes muebles e inmuebles. Si el bien inmaterial aportado es expropiado por el Estado, junto con la patente por motivos de interés público o 
social, conforme a lo previsto por el artículo 565 del Código de Comercio, se debe indemnizar al expropiado y con base en los precios reales o valores efectivos que correspondan.

Estos puntos deben estar contenidos en los acuerdos preliminares al momento de suscribir el contrato de joint venture, al momento de formar la operación conjunta, no obstante que en principio no se haya dicho nada sobre el particular.

Y la cuantificación es otro aspecto medular, que da origen a múltiples controversias jurídicas, pues no es fácil valorar este tipo de aportes en las negociaciones preliminares, ni mucho menos existen normas o criterios uniformes sobre el método de valoración financiero y empresarial de patentes y know how en el marco de los acuerdos de joint venture; indiscutiblemente, se está en presencia de un terreno virgen, francamente inexplorado por la doctrina y la jurisprudencia colombiana

\subsection{CONSTITUCIÓN DE SOCIEDADES Y FIDEICOMISOS EN LA FORMACIÓN DEL JOINT VENTURE}

Otro de los puntos que también amerita la atención es el concerniente a la constitución de sociedades como vehículo de inversión del acuerdo de joint venture y de fideicomisos mercantiles sobre el particular. Al constituirse, por ejemplo, sociedades comerciales por acciones, algunas legislaciones como la estadounidense permiten las acciones al portador, al igual que los Estados que se consideran paraísos fiscales, verbigracia, Panamá, Hong Kong, Malasia, entre otros 8Cfr. LÓPEZ GUZMÁN, 2012; RAVASSA, 2005).

En nuestra legislación estaban permitidas las acciones al portador, pero fueron suspendidas por la decisión 291 de 1991 del acuerdo de Cartagena, por considerar que se podrían infiltrar capitales provenientes de actividades ilícitas y que su inclusión era útil y apropiada para el blanqueo de capitales. 
Es factible que en un joint venture internacional se requiera la constitución de una sociedad comercial por acciones, y que con base en la legislación del país elegido por las partes, se admitan las acciones al portador. Para el caso colombiano, es importante que se reconsidere la activación de esta clase de acciones de sociedades, toda vez que existen muchos mecanismos legales en nuestra legislación para proteger a los empresarios de compañías que quieran hacer blanqueo de capitales y que se dediquen a actividades ilegales.

Las acciones al portador fortalecen el sistema económico, aumentan o mejoran el mercado bursátil interno, entre muchas otras ventajas, como, por ejemplo, mantener la reserva de un inversionista internacional. Toda esta problemática debe ser contemplada en la fase preliminar del acuerdo de joint venture. Nada se ha dicho en la doctrina sobre la materia (Cfr. PARRA, 2004; SIERRALTA, 1996; COLAIÁCOVO, 1992), no hay posturas jurídicas al respecto, es un área inexplorada y que debe ser analizada con más atención por la doctrina y por el legislador. Se propone aquí la reactivación de las acciones al portador, máxime para los contratos o acuerdos de joint ventre internacional donde participan varios empresarios que conformarán la operación conjunta.

Ahora bien, en lo tocante a los fideicomisos como vehículos de inversión, tampoco nada ha manifestado la doctrina al respecto. Ciertamente, la ejecución de un proyecto de alta tecnología, o de un proyecto que requiere ingentes inversiones por los socios venturistas, se puede canalizar por intermedio de un fideicomiso de inversión internacional (Cfr. RODRíGUEZ AZUERO, 2005). Es en la fase previa donde se deben especificar este tipo de situaciones y métodos o mecanismos para el manejo y administración de los recursos (Cfr. PAULEAU, 2003; LE PERA, 1984). En este periodo o etapa del contrato, existe también un alto grado de responsabilidad entre los potenciales socios; es decir, en la fase preliminar del contrato de joint venture se habla asimismo de la responsabilidad precontractual. 
Dicha responsabilidad no es inherente tan sólo al decurso de la fase contractual, sino que también está presente en la etapa inicial o previa. De ahí que la doctrina, la jurisprudencia y la ley, hayan desarrollado la teoría de la responsabilidad precontractual, que luego se materializó el ordenamiento jurídico colombiano.

En efecto, el artículo el artículo 863 del Código de Comercio colombiano, declara: "Las partes deberán proceder de buena fe exenta de culpa en el periodo precontractual, so pena de indemnizar los perjuicios que se causen". Ello se funda en el principio de que los contratos deben ejecutarse de buena fe (C. C., art. 1603). En la misma línea se expresa el artículo 1337 del Código de Derecho Privado Italiano, cuando estipula que, "en el desarrollo de las etapas preliminares y en la formación el contrato, las partes deben comportarse de buena fe". A la par, los Principios de Unidroit en su artículo 1.7, manifiestan: “(1) Las partes deben actuar con buena fe y lealtad negocial en el comercio internacional. (2) Las partes no pueden excluir ni restringir la aplicación de este deber. A su vez, el artículo 2.15 del mismo ordenamiento internacional, establece: "Negociaciones con mala fe. (1) Cualquiera de las partes es libre de entablar negociaciones no incurre en responsabilidad en el supuesto de que estas no culminen en acuerdo. (2) Sin embargo, la parte que ha negociado, o ha interrumpido las negociaciones con mala fe será responsable por los daños causados a la otra parte. (3) En especial, se considera mala fe en entrar en negociaciones o continuarlas con la intención de no llegar a un acuerdo".

En lo que atañe a la motivación de los posibles socios del joint venture para concluir el acuerdo, puede afirmarse que esta se constriñe primordialmente al interés comercial de acceder a la explotación de un negocio o proyecto que va a reportar importantes beneficios o utilidades. Ello supone el éxito de la inversión.

Empero, como en todo negocio o actividad mercantil, hay riesgos que se deben soportar. Hay empresas ilegales y dedicadas a operaciones mercantiles prohibidas 
por la ley. De ahí que sea menester examinar con suma atención el tipo de socio y la experiencia que este tiene en el proyecto respectivo.

En los contratos de joint venture y en las asociaciones a riesgo compartido hay fraudes de toda clase y existen empresas que tan sólo quien aprovecharse de la reputación empresarial ajena, de la tecnología, de los recursos o del trabajo de otras compañías. Muchas de estas malas experiencias empiezan en la fase de formación del contrato y sobre todo en los contratos con el sector público, donde se emplean algunas formas de agrupación empresarial o subtipos de joint ventures y alianzas estratégicas, como, por ejemplo, en las uniones temporales y en los consorcios a que se refiere la ley 80 de 1993 (PARRA, 2004).

Diversas controversias en este ámbito han surgido por la mala planificación desde el comienzo, por no fijar claramente las obligaciones dimanantes del contrato desde la fase preliminar, y en los que la responsabilidad (consorcios y uniones temporales) es diferente, según lo dispone la ley y lo precisa la jurisprudencia (Cfr. LAMPREA RODRÍGUEZ, 2007; CABALLERO SIERRA, 1985) ${ }^{11}$. Así, por ejemplo,

11 “Como lo precisa el Consejo de Estado, la legislación del consorcio no pasa de las escuetas disposiciones de la ley 80; de donde infiere que es $<<$ contrato asociativo de empresas 0 empresarios, que se vinculan económica, jurídica o técnicamente para cierta actividad común, sin disponer de personalidad jurídica diferente a la de los consorciados, que conservan facultad autónoma de decisión >> (C. de Co., art. 98). El consorcio no es <<sociedad de hecho〉>, pues carece de sus presupuestos (arts. 498 y 499 ibidem).

"Entre los miembros del consorcio nacen obligaciones que contraen respecto del destinatario de la propuesta, por mutuo acuerdo, que las obliga entre sí pero no respecto de tercero (...)".

“(...) El Consejo de Estado fija los rasgos esenciales el consorcio y de la unión temporal, tan sólo distintos en aspectos que precisa la ley, declarando que cada uno es $<<$ negocio jurídico, de más de un sujeto de derecho, asociados transitoriamente para formar capacidad común con un fin determinado, al que la ley no atribuye personalidad jurídica>>. Por esta carencia, el consorcio no constituye persona distinta de los integrantes individualmente considerados. Según la ley 80 , el propósito del consorcio y de la unión temporal es <<proponer conjuntamente para la adjudicación del contrato, con responsabilidad solidaria en las obligaciones resultantes. Los actos, hechos y omisiones del consorcio afectan a quienes lo conforman>>. A juicio del Consejo de Estado, tampoco es sociedad irregular, ni de hecho. Menos puede considerarse como cuenta en participación. El registro del consorcio como establecimiento de comercio en la cámara de comercio constituye solo medio de publicidad y nada más. 
los contratos de joint venture mineros, petroleros, en materia de telecomunicaciones y, recientemente, en el caso del proyecto vial autopistas de la montaña.

Habiéndose lesionado o vulnerado la confianza entre los posibles socios del joint venture, sea porque uno de ellos retira la oferta sin motivo justificado, por imposibilidad de desarrollar el proyecto o porque el contrato resulta inexistente 0 nulo, conforme a un ordenamiento jurídico determinado, el empresario afectado o lesionado a nivel patrimonial tiene derecho a que se le resarzan los perjuicios causados para compensar los menoscabos de toda índole, materiales y morales según la doctrina moderna, resultantes de la frustración del contrato de joint venture nacional o internacional.

De otra parte, hay que desterrar la idea de que la asociación empresarial entre compañías locales es mala de por sí, y que todas las compañías extranjeras son magníficas y aventajadas y que ofrecen bienes y servicios de óptima calidad. En verdad, es un asunto muy relativo, y precisamente, la función de los contratantes en la etapa previa de formación del negocio de joint venture, es puntualizar los aspectos fundamentales del contrato, respetando los derechos y las garantías sustanciales y procesales a nivel precontractual, dado que la responsabilidad está presente aquí (En Igual sentido, cfr. PAULEAU, 2003).

“En la práctica, el consorcio y la unión temporal se rigen por acuerdo de integrantes (contrato de colaboración económica) en que se designa a uno de ellos como representante convencional para los efectos del contrato.

"Crear consorcio es hacer real la posibilidad de reunir esfuerzos, conocimientos, capacidad técnica y científica, de un grupo de personas, en busca de la adjudicación de contrato estatal. Cada integrante conserva autonomía y facultad de decisión. La duración del consorcio se condiciona a la vigencia del contrato y al plazo que el contratista tiene para ejecutar la obra o prestar el servicio. Los integrantes del consorcio responden solidariamente por la ejecución del contrato. La ley prohíbe la cesión del contrato entre sus integrantes" (LAMPREA RODRÍGUEZ, 2007, pp. 195, 197 y 198). 


\subsection{RUPTURA INJUSTIFICADA DE LAS NEGOCIACIONES EN LA FORMACIÓN DE LOS JOJNT VENTURE}

La ruptura injustificada de las negociaciones es también otro punto de vital interés, pues el empresario o compañía que se retira intempestivamente perjudicando a sus potenciales socios, está obligado a indemnizar los daños y perjuicios que cause con su conducta.

Es uniforme la tendencia en el derecho comparado en el sentido de obligar al contratante incumplido a resarcir los perjuicios causados por terminación injustificada de las negociaciones.

Ciertamente, "los Códigos alemán y chino admiten expresamente la responsabilidad por culpa in contrayendo cuando la declaración de voluntad hecha por una persona a otra es anulada por una causal imputable a su autor, siempre que la otra ignore esta causal (art. 122 del Código alemán y art. 91 del chino) y cuando una persona contrata con otra sabiendo o debiendo saber que la prestación materia del contrato es imposible y la otra ignoraba esta imposibilidad (arts. 307 del Código alemán y 247 del chino). El artículo 57 del Código de las Obligaciones de Polonia dispone igualmente que la parte que al tiempo de la celebración del contrato conocía la imposibilidad de la prestación debe reparar el daño causado a la otra que contrató ignorando esta imposibilidad. A su vez, los Códigos de las Obligaciones de Suiza (art. 26) y Turquía (art. 36) y el Código Civil de Venezuela (art. 1149) establecen que la parte que alega su error para invalidar el contrato está obligada a reparar a la otra parte el daño causado con la nulidad del mismo contrato si ese error es imputable a culpa suya, a menos que el otro contratante haya conocido o debido conocer ese error" (ALESSANDRI RODRÍGUEZ, 1998, p. 160).

Ahora bien, la indemnización de perjuicios por terminación injustificada en la fase preliminar comprende el daño emergente, el lucro cesante y el daño moral 
provocados por la ineficacia de las negociaciones. Estos conceptos engloban, en primer lugar, las pérdidas ocasionadas por los gastos e inversiones ocasionados con motivo de las negociaciones primigenias, las ganancias frustradas y los beneficios ciertos que se hayan dejado de percibir en razón a que el contrato de joint venture no produjo los beneficios y utilidades esperadas.

Evidentemente, los acuerdos preliminares están orientados al perfeccionamiento del contrato de joint venture; si cualquiera de las partes obra de mala fe, deberá resarcir los perjuicios que se causen.

Las razones que motivan a un parte a incumplir, desde el punto de vista empresarial, se reducen por lo general a los siguientes: la mala fe, las prácticas colusorias de los competidores que pretenden impedir el acceso de otros empresarios al mercado específico mediante la terminación anticipada e injusta de las negociaciones preliminares de alianzas estratégicas y joint ventures; la publicidad engañosa; las empresas ilegales y la competencia desleal.

Aparte de todo lo anterior, en la fase perfectiva del contrato de joint venture las partes o los socios potenciales se disponen a concluir el contrato nacional o internacional. Así, pues, el inversionista interesado en adelantar un proyecto conjunto le hace la respectiva oferta a los demás empresarios, sea sociedades mercantiles, fundaciones, entidades sin ánimo de lucro interesadas en desarrollar proyectos de carácter social o cultural (Cfr. JARAMILLO DÍAZ, 2014), o empresas multinacionales, y si el destinatario acepta se forma el contrato de joint venture; en algunos casos se forma por la conducta concluyente de las partes o de los asociados, según lo dictamina el artículo 2.1 de los Principios de Unidroit sobre los contratos comerciales internacionales (Cfr. PEÑA NOSSA, 2014).

Las condiciones de la oferta mercantil, su aceptación, el rechazo, la caducidad, el perfeccionamiento, la modificación o la extinción del contrato se sujeta a una legislación estatal. Las normas aplicables a esta fase formativa del contrato serán 
las de orden público que rijan el negocio jurídico, de acuerdo con el vínculo legal existente, sea por la nacionalidad de las partes, el domicilio de las sociedades, el lugar de celebración y/o ejecución del contrato de joint venture o, en definitiva, el contrato se regirá por la legislación escogida por las partes al momento de celebrar el contrato de asociación a riesgo compartido.

En los contratos estrictamente nacionales, es decir, en los que no existe un elemento de extranjería, la legislación aplicable es la nacional del Estado donde se celebra y ejecuta el contrato mercantil que aquí se estudia. En defecto de elección del derecho aplicable al contrato de joint venture por los socios inversionistas, será la que establezca el tribunal de arbitramento, con base en los puntos de conexión y las reglas del derecho internacional de contratación (Cfr. Convenio de Roma de 1980; Convenio de México de 1994; Principios de Unidroit de 2010; Convenio de Viena de 1980 sobre compraventa internacional, entre otros. Así mismo, cfr. RAVASSA MORENO, 2004; FERNÁNDEZ DE LA GÁNDARA y CALVO CARAVACA, 1995).

La elección del derecho aplicable en la fase formativa del contrato no es un asunto que deba menospreciarse en una negociación de joint venture. Lo más aconsejable en este punto es dilucidar desde el comienzo el derecho y la jurisdicción aplicable para el contrato de joint venture internacional, es decir, para los contratos de asociación en los que los socios inversionistas son de distintas nacionalidades y donde el contrato se celebra y ejecuta en diferentes países.

Lo anterior por cuanto que los principios y normas aplicables a la formación del contrato internacional de joint venture difieren en los distintos sistemas jurídicos. Así, por ejemplo, en los "derechos latinos la confluencia de oferta y aceptación forman el consentimiento, y este el contrato.

En el derecho del common law además de la confluencia de la oferta y de la aceptación es necesaria la existencia de la consideration, que es un principio de 
ejecución, pudiendo estar representado por un pago simbólico de un dólar en Estados Unidos de América" (MARZORATI, 2003, T. I, p. 132).

En lo que respecta a la oferta, algunos países como los del common law, han optado por el sistema de la emisión; o sea, que la oferta se formaliza y se materializa con la simple emisión al destinatario.

Otros, como los de los derechos romano-germánicos, se inclinan por el sistema de la recepción, es decir, que el negocio se forma cuando el destinatario ha recibido y expresado su aceptación del negocio propuesto de joint venture. todo ello es relevante a la hora de realizar un contrato de joint venture, toda vez que para un empresario estadounidense el consentimiento es eficaz desde el momento de la emisión (mailbox rule) de la oferta.

En contraste, para un posible socio colombiano o latinoamericano de la operación de joint venture, hay oferta cuando esta es firme, inequívoca y precisa, completa, es un acto voluntario del oferente, está dirigida al destinatario y llega a su conocimiento, según lo indicó la Corte Suprema de Justicia de Colombia, en sentencia de casación civil de 8 de marzo de 1995.

Nada obsta para que los socios potenciales del negocio de joint venture escojan como derecho aplicable a la formación del contrato, es decir, a la fase preliminar los Principios de Unidroit de 2010 sobre los contratos comerciales internacionales.

Si bien es cierto que los principios enunciados son insuficientes, genéricos, aplicables a cualquier tipo de contrato internacional, las partes del negocio de joint venture pueden complementar esta legislación con un ordenamiento jurídico nacional o internacional, en cuyo caso se estará hablando de un típico depeçage o fraccionamiento voluntario de la ley. Conocidas en su totalidad las condiciones generales del joint venture por los potenciales socios, podrán decidir si suscriben o no el contrato tantas veces mencionado. 
Ahora bien, dado que en esta clase de contratos, por lo regular la parte fuerte o dominante se impone, se diseñan formularios o formatos de contratación en los que la parte débil, o las empresas con menor poder económico, deben suscribirlo con escaso poder de negociación y discusión (Cfr. SIERRALTA, 2007).

No obstante, el punto es discutible, digno de analizarse desde la perspectiva de las cláusulas abusivas.

Un sector de la doctrina opina que en estricto rigor no se trata de un contrato de adhesión, sino de libre discusión, dado que los socios inversionistas han tenido la oportunidad de conocerse, pensar, discutir y controvertir el contenido del contrato de joint venture que se le propone.

Este criterio es compartido por un amplio sector de la doctrina; sin embargo, no se puede desconocer el hecho de que la parte fuerte sí impone las condiciones de contratación, sí impone cláusulas en su favor; de manera que en este plano es mejor ser más realistas, puesto que quien ostenta el poder en el mercado, está en capacidad de diseñar e imponer el clausulado del contrato de joint venture.

En todo caso, si el potencial socio o socios descubren que el clausulado del contrato de joint venture es abusivo, lesivo para los demás contratantes por romper el equilibrio financiero y los derechos y garantías sustanciales y procesales, el juez o el tribunal de arbitramento pueden declarar que son nulas 0 ineficaces y, por ende, inaplicables a la relación contractual de joint venture.

Aunque para que ambas partes puedan acudir ante un tribunal de arbitramento, es menester que los potenciales socios de la joint venture hayan pactado una cláusula arbitral internacional (Cfr. FRIEDLAND y LLANO ODDONE, 2010). 
En algunos países el hecho de atentar contra la armonía y equilibrio del contrato no sólo constituye sanción grave sino que, a su vez, implica violación a las normas sobre la libre competencia económica. Amén de los problemas jurídicos que se ocasionan por la batalla de los formularios, es decir, por el envío y recepción de diversos formatos para concluir el negocio de joint venture.

Para complementar todo lo que se ha dicho hasta esta parte, conviene traer a colación las explicaciones que sobre el particular enseña la doctrina (PAULEAU, 2003, pp. $351-355)$ :

"En la práctica, los juristas vinculan frecuentemente la elección de la ley nacional aplicable al contrato a la cláusula que designa la jurisdicción judicial o arbitral competente en caso de funcionamiento <<patológico >> del mismo, situándola, por regla general, entre las disposiciones finales. No obstante, dicha elección deberá hacerse, efectivamente, antes de la redacción del contrato (fase preliminar). En este sentido, el jurista tendrá que asegurarse, con anticipación, del régimen jurídico aplicable al contrato a fin de aportar, en su propio texto, las soluciones a las consecuencias que se derivan de él para las empresas partes.

Concretamente, la ley del contrato determinará el tratamiento reservado a cuestiones esenciales, tales como el consentimiento de las partes (tanto respecto a su validez como a los vicios que pueden afectarle), la licitud de la causa del contrato, la interpretación de las cláusulas ambiguas, los efectos del contrato frente a terceros, la revisión del contrato, las consecuencias del incumplimiento del contrato (resolución, responsabilidad contractual) o la prescripción de las acciones en responsabilidad.

"En el contexto de una alianza transnacional, el problema esencial consistirá en vincular el contrato de joint venture al ordenamiento nacional más adecuado. De conformidad con el principio de autonomía de la 
voluntad, los contratantes pueden elegir libremente la ley aplicable, siempre que dicha elección respete las normas de orden público internacional existentes en los distintos ordenamientos respecto a los cuales la validez del contrato es susceptible de apreciarse.

Dentro del marco de dicha libertad, las partes podrán decidir, en especial, sustraer el contrato a la aplicación de toda ley nacional, construyendo por sí mismas, punto por punto, su propia regulación contractual. Los juristas suelen recomendar que dicha intención sea expresamente afirmada en el contrato para evitar que el juez interprete el silencio de las partes como una voluntad presumida de someter el contrato a alguna ley nacional con la que su ejecución presente una conexión. Las partes podrán también hacer referencia a los usos del comercio internacional, a la lex mercatoria, o someter el contrato a arbitraje y establecer que los árbitros decidirán en equidad.

"Todas las opciones descritas anteriormente aseguran, en realidad, una mayor adecuación entre e régimen aplicable al contrato, que es ampliamente definido por los propios contratantes, y el objeto contractual.

Ahora bien, en el contexto específico de las joint ventures estructuradas, dichas opciones presentan ciertas dificultades, debido a la presencia de la sociedad <<filial común >> en su seno.

Efectivamente, las empresas partes no podrán sustraerse al ordenamiento jurídico que precisamente regula la forma societaria adoptada por la filial común, sea por razón del lugar en el que se sitúe su domicilio real, del lugar de su constitución (o incorporación), o del lugar desde el cual sus socios ejercen el control. Esta vinculación necesaria de la filial común a una ley nacional determinada puede ser problemática a la hora de adaptar el régimen de su organización y funcionamiento para hacer de ella una <<técnica de organización de una alianza entre empresas>>, considerando, 
en especial, la presencia tradicional de numerosas normas imperativas que tienden a <<institucionalizar >> las formas societarias capitalistas en los ordenamientos europeos continentales.

"En todo caso, la doctrina especializada en materia de joint venture recomienda unánimemente, por razón de seguridad jurídica, que las empresas fundadoras elijan expresamente la ley aplicable al contrato de joint venture. Los autores precisan que no es obligatorio someter la totalidad del contrato a una misma ley estatal. Concretamente, las empresas podrán elegir, según ellos, una ley aplicable al conjunto de la organización de la joint venture y sustraer algunos de sus elementos de la aplicación de la misma para situarlos bajo el imperio de otra ley nacional. También pueden no elegir una ley de conjunto y someter cada elemento presente en la organización jurídica de la joint venture a distintas leyes nacionales.

Finalmente, en cuanto a la ley concreta sobre la que las empresas deben pactar, puede tratarse tanto de la ley de los países con los que la alianza presenta alguna conexión, como de una ley neutra, sin ningún vínculo aparente con el contrato y sus partes, siempre que esta elección respete las normas de orden público internacional susceptibles de aplicarse, en especial en relación a la sociedad constituida en el seno de la alianza”.

\section{CONCLUSIONES}

Con relación al derecho colombiano, conviene precisar los siguientes en torno del contrato de joint venture:

1. El contrato de joint venture es un negocio jurídico contemporáneo, cuyo origen se remonta al derecho anglosajón (inglés y norteamericano), mediante el cual varias personas naturales y/o jurídicas aportan bienes 
muebles, inmuebles o propiedad intelectual, con el propósito de desarrollar un proyecto en común durante un tiempo determinado y repartirse los beneficios o utilidades al finalizar la actividad, compartiendo asimismo los riesgos inherentes a la operación conjunta.

2. El contrato de joint venture es un contrato mercantil, de colaboración empresarial, atípico, innominado, consensual, de ejecución sucesiva, oneroso, bilateral o plurilateral, y que se ha trasplantado a nuestro sistema contractual interno para el desarrollo de diversas actividades y operaciones mercantiles.

3. El contrato de joint venture puede ser nacional o internacional. Si es nacional está sujeto a la aplicación de la legislación colombiana, y más concretamente el régimen de obligaciones y contratos previsto en los Código Civil y de Comercio. Se suele confundir o identificar con las uniones temporales, los consorcios y las sociedades de hecho; sin embargo, si bien es cierto que guarda cierta similitud con dichas figuras jurídicas, es un negocio jurídico autónomo, con características propias y de gran trascendencia e importancia en el ámbito del derecho de los negocios. Las uniones temporales y los consorcios, regulados por la ley 80 de 1993, puede decirse que son subespecies del contrato de joint venture, pero no un joint venture en estricto rigor jurídico, y mucho menos una sociedad comercial de hecho, pues goza de mayor autonomía entre las partes, permite la creación de una sociedad comercial en el acuerdo base de joint venture, posee las características y elementos del joint venture internacional anglosajón y está destinado a servir de instrumento jurídico a grandes proyectos de infraestructura y obras, no obstante que también se puede emplear para transferir tecnología, distribuir bienes y mercancías, penetrar en mercados extranjeros y ofrecer mejores servicios en el ámbito educativo (joint ventures educativos, por ejemplo). 
4. El contrato de joint venture se desnaturalizó ciertamente en el derecho colombiano, porque como pudo analizarse detenidamente en la presente investigación, desde la perspectiva de la noción, sus elementos y características, la figura ha mutado, tratando de adapartarse al derecho colombiano mediante las uniones temporales y los consorcios a que se refiere la ley 80 de 1993. Y como se demostró a lo largo de esta investigación, la desnaturalización no sólo empezó con una incorrecta fusión de la figura en estas modalidades de contratación estatal, sino también en los yerros que se han propuesto a nivel doctrinal en lo que respecta a su definición, elementos y características, así como al hecho de que en la ley 222 de 1995 que reformó el Código de Comercio se omitió el capítulo correspondiente a las uniones de empresas, a diferencia de lo que acontece en el derecho argentino y europeo, así como en la legislación del MEFCOSUR. Por tanto, mi propuesta está orientada a una redefinición de la figura, a que se expida una legislación comercial más precisa sobre el uso de la figura en el derecho nacional, con base en los principios y normas del derecho mercantil internacional, y no con base en visiones exclusivamente parroquiales o locales.

5. El contrato de joint venture es un contrato selectivo y no intuitu personae, se caracteriza por ser un negocio jurídico en el que predomina el elemento intuitu instrumenti y no el intuitu personae, pues los potenciales socios son elegidos no por sus cualidades personales, sino por el cumplimiento de un conjunto de requisitos objetivos de contratación.

6. El contrato de joint venture se puede someter, en lo que respecta a la legislación aplicable, a la legislación nacional o a la legislación internacional, o en definitiva, pueden aplicarse diversas legislaciones mediante el sistema del fraccionamiento voluntario de la ley. Asimismo, puede adaptarse para negocios privados, públicos o internacionales, de acuerdo a las necesidades específicas que tengan los asociados. Igualmente, cabe resaltar que en el acuerdo base se pueden constituir sociedades comerciales, entidades sin ánimo de lucro, o celebrar contratos 
de fideicomiso civil o mercantil para el desarrollo y ejecución de la operación conjunta.

7. Hay diversos tipos de joint ventures, dependiendo de la clase de negocio $u$ operación mercantil que quieren llevar a cabo los asociados. Entre tanto, es menester agregar que el riesgo es compartido entre los asociados, o sea, que se reparten las pérdidas o las utilidades o beneficios obtenidos con el ejercicio o actividad mercantil específica. El objeto social puede ser determinado o indeterminado; la duración del joint venture puede ser definida o indefinida, conforme a los requerimientos de los empresarios asociados.

8. En lo que respecta al registro mercantil del contrato, no es menester que las partes se dirijan a la Cámara de Comercio del domicilio de las compañías asociadas para registrar el contrato. Eso no lo exige la ley. Sin embargo, si en el acuerdo base de joint venture las partes deciden constituir una sociedad mercantil, como es obvio, esta sí requiere del trámite del registro mercantil para efectos de oponibilidad ante terceros y porque así lo exige la ley (C. de Co., art. 28). Sin embargo, si las partes tan sólo suscriben un contrato mercantil de joint venture, no se requiere tal registro ni tampoco es menester su autenticación ante notario, o sea, el reconocimiento de las firmas ante notario para su validez o eficacia, ya que las firmas estampadas en el contrato se presumen auténticas, en desarrollo del principio de buena fe consagrado en la Constitución Política de 1991, así como en el derecho sustancial y procesal interno, y en virtud de los principios de consensualidad e informalidad.

9. A los contratos joint venture se le pueden aplicar los Principios y normas del derecho internacional, también denominados lex mercatoria o ley del comercio global. Así mismo, nada obsta para que a un negocio mercantil de esta naturaleza se le apliquen las normas de un tratado o convenio internacional en materia comercial. El hecho de no estar precisamente regulado en un ordenamiento jurídico específico le confiere a las partes amplia autonomía para el diseño del negocio, tanto autonomía material 
como conflictual. Por la primera, las partes están facultadas para escoger el contenido y la forma del contrato; por la segunda, las partes contratantes del joint venture pueden elegir el ordenamiento jurídico aplicable a su relación jurídica. En aquellos casos donde el joint venture ejecuta sus actividades en varios países, igualmente se deben cumplir las normas internas de orden público sobre régimen financiero, cambiario e inversión extranjera.

10. El contrato se forma por el consentimiento de los potenciales socios, previa oferta y aceptación de cada uno de ellos. Durante la formación del contrato de joint venture se debe respetar la confidencialidad de la información suministrada por los demás socios inversionistas; de lo contrario, se incurre en actos de competencia desleal. El contrato se puede formar entre presentes mediante la suscripción de un acuerdo, o por intermedio de un mensaje de datos (contratación electrónica), conforme a la ley 527 de 1999. Si se causan perjuicios a las partes durante la etapa de formación del contrato, se deben indemnizar, y esta comprende: el lucro cesante, el daño emergente y los daños morales en la actualidad, habida cuenta que la doctrina y la jurisprudencia contemporánea propugnan la ampliación del cobro de los perjuicios.

11. En el contrato de joint venture se puede pactar convenio arbitral con objeto de resolver las controversias que puedan presentarse entre las partes. De hecho, es lo más conveniente, por cuanto el sometimiento a la ley y la jurisdicción común presenta muchos inconvenientes, dado que hay muchas instancias judiciales, subsiste la morosidad judicial, y además no hay un conocimiento profundo y adecuado en el ámbito de la jurisdicción ordinaria de este tipo de contratos. Por ello, lo más aconsejable es que por lo regular se pacte un convenio arbitral, máxime por cuanto este tipo de justicia alternativa es más ágil y conoce mejor las nuevas modalidades de contratación nacional e internacional (A este respecto, cfr. ZAPATA DE ARBELÁEZ y otros, 2010; MARTíNEZ NEIRA, 2014, pp. 747 - 777). El contrato de joint venture presenta muchas ventajas, no se le debe temer a 
su aplicación e implementación en todos los sectores económicos, pese a que se trate de un trasplante jurídico del derecho norteamericano principalmente. Y, por último, desde el comienzo las partes deben estipular la legislación y la jurisdicción aplicable al contrato, determinar quién va a administrar los recursos y la alianza estratégica, con el propósito de que las responsabilidades estén claramente determinadas desde el comienzo del negocio u operación conjunta. 


\section{REFERENCIAS}

1. ALESSANDRI RODRíGUEZ, ARTURO (1997): De los contratos, Chile, Editorial Jurídica de Chile.

2. ALMONACID SIERRA, JUAN JORGE y GARCÍA LOZADA, NELSON GERARDO (1998): Derecho de la competencia, Bogotá, Legis Ediciones.

3. ARCE GARGOLLO,JAVIER(1989): Contratos Mercantiles Atipicos, Mexico, Editorial Trillas.

4. ARRUBLA PAUCAR,JAIME ALBERTO(1998):Contratos Mercantiles, Tomo II ,Contratos Atípicos, Tercera edición, Medellín, Biblioteca Jurídica

5. ASCARELLI, TULIO (1970): Teoría de la concurrencia y los bienes inmateriales, Barcelona, Bosch Casa Editorial.

6. ASTOLFI, ANDREA (1986): EL contrato internacional de joint venture, Buenos Aires, Editorial Depalma.

7. BANCO DELA REPÚBLICA (1998): Introducción al análisis económico. El caso colombiano, Bogotá, Siglo del Hombre Editores.

8. BARONA VILAR, SILVIA y otros (1999): Contratación internacional, Valencia, Editorial Tirant lo Blanch.

9. BARRERO BUITRAGO, ALVARO (2006): Manual Para el Establecimiento de Sociedades ,Bogotá, Librería Ediciones del Profesional Limitada. 
10.BOGGIANO, ANTONIO (1985): Sociedades y grupos multinacionales, Buenos Aires, Editorial Depalma.

11.BONILLA MALDONADO, DANIEL (2009): Teoría del derecho y trasplantes jurídicos, Bogotá, Siglo del Hombre Editores - Universidad de los Andes Pontificia Universidad Javeriana - Instituto Pensar.

12. BRAVO MELGAR, SIDNEY ÁLEX (1997): El contrato de joint venture, Lima, Editorial Jurídica Grijley.

13. BRUNETTI, ANTONIO (2002): Sociedades Mercantiles, Tomo I, México, Editorial Jurídica Universitaria.

14. CABALLERO SIERRA, GASPAR (1985): Los consorcios públicos y privados, Bogotá, Editorial Temis.

15. CABANELLAS DE LAS CUEVAS, GUILLERMO y KELLY, JULIO ALBERTO (1987): Contratos de colaboración empresaria. Agrupaciones de colaboración, uniones transitorias de empresas y joint ventures, Buenos Aires, Editorial Heliasta.

16. CALVO CARAVACA, ALFONSO-LUIS y otros (1997): Contratación internacional, Madrid, Editorial Tecnos.

17. Código Civil, Bogotá, Editorial Leyer, 2014.

18. Código de Comercio, Bogotá, Editorial Leyer, 2014.

19. COLAIÁCOVO, JUAN LUIS (1991): Negociación y contratación internacional, Buenos Aires, Editorial Macchi. 
20. COLAIÁCOVO, JUAN LUIS; AVARO, RUBÉN DANIEL; ROSADO DE SA RIBEIRO, MARILDA; y CARBONA VELIZ, HERNÁN (1992): Joint ventures y otras formas de colaboración empresarial, Buenos Aires, Editorial Macchi.

21. Constitución Política de 1991, Bogotá, Editorial Leyer, 2014.

22. CORTÁZAR MORA, JAVIER (2003): Hacia un nuevo derecho de la competencia en Colombia, Bogotá, Ediciones Doctrina y Ley.

23. CORREA ARANGO, GABRIEL (2013): Comentarios al estatuto de arbitraje y amigable composición, Bogotá, Editorial Temis.

24. CZINKOTA, MICHAEL R., y RONKAINEN, ILKA A (2002): Marketing internacional, México, Pearson Educación.

25.DANIELS, JOHN D., y RADEBAUGH,LEE H (2000): Negocios internacionales, México, Pearson Educación.

26. DE LA MADRID ANDRADE, MARIO (2005): El joint venture. Los negocios jurídicos relacionados, México, Editorial Porrúa.

27. DERAINS, YVES y SCHWARTZ, ERIC A. (2001): El nuevo reglamento de la Cámara de Comercio Internacional, México, Oxford University Press.

28. DIAZ BRAVO, ARTURO (2005):glosario jurídico mercantil, Mexico, IURES Editores S.A. 
29. DIAZ BRAVO, ARTURO(2005):Derecho Mercantil, México, IURES Editores S.A.

30.DÍEZ HOCHLEITNER, JAVIER y MARTÍNEZ CAPDEVILA, CARMEN (2001): Derecho de la Unión Europea. Textos y comentarios, Madrid, McGraw-Hill.

31.ECHARRI, ALBERTO; PENDÁS AGUIRRE, ÁNGEL y DE QUINTANA SANZ-PASTOR, ANA (2002): Joint venture, Madrid, FC Editorial.

32.FARIA, JOSÉ EDUARDO (2001): El derecho en la economía globalizada, Madrid, Editorial Trotta.

33. FARINA, JUAN M (1999): Contratos comerciales modernos, Buenos Aires, Editorial Astrea.

34.FARINA, JUAN M (2011): Derecho de las sociedades comerciales, tomo I, Buenos Aires, Editorial Astrea.

35. FERNÁNDEZ DE LA GÁNDARA y CALVO CARAVACA, ALFONSO-LUIS (1995): Derecho mercantil internacional, Madrid, Editorial Tecnos.

36. FLINT BLANK, PINKAS (2000): El uso de figuras jurídicas y financieras en épocas de crisis, en la Revista Juris Consulta, NUM. 4, Reestructuración de empresas en crisis. Ley 550 de 1999, Cámara de Comercio de Bogotá.

37. FRIEDLAND, PAUL y LLANO ODDONE, RAFAEL E (2010): Cláusulas de arbitraje para contratos internacionales, Buenos Aires, Editorial AbeledoPerrot. 
38. GARRIGUES, JOAQUÍN (1971): Hacia un nuevo derecho mercantil, Madrid, Editorial Tecnos.

39. GAVIRIA GUTIÉRREZ, ENRIQUE (1996): Nuevo régimen de sociedades, Medellín, Editorial Diké.

40. GIL ECHEVERRY, JORGE HERNÁN (2013): Derecho arbitral colombiano, Bogotá, Grupo Editorial Ibáñez.

41.GIL ECHEVERRY, JORGE HERNÁN (2012): Derecho societario contemporáneo. Estudios de derecho comparado, Bogotá, Legis Ediciones.

42. GIRALDO BUSTAMANTE, ALEJANDRO (2005): El contrato de joint venture, en AA. VV., Contratos atípicos, Bogotá, Cámara de Comercio de Bogotá.

43. GÓMEZ LEYVA, DELIO (1998): De las restricciones, del abuso y de la deslealtad en la competencia económica, Bogotá, Cámara de Comercio de Bogotá.

44. GUARDIOLA SACARRERA, ENRIQUE (1998): Contratos de colaboración en el comercio internacional, Barcelona, Bosch Casa Editorial.

45. HILL, CHARLES L. W (2001): Negocios internacionales, México, McGrawHill.

46. IDROVO CUBIDES, JUAN MANUEL (2005): Principios básicos de las inversiones. Seis países de América Latina, Bogotá, Legis Ediciones. 
47.JARAMILLO DÍAZ, JUAN CARLOS (2014): Entidades sin ánimo de lucro. Régimen legal y tributario.

48. JULIÁ BARCELO, ROSA (2000): Comercio electrónico entre empresas. La formación y prueba del contrato electrónico, Valencia, Editorial Tirant lo Blanch.

49. KOZOLCHYK, BORIS (2006): La contratación comercial en el derecho comparado, Madrid, Editorial Dykinson.

50. LAMPREA RODRÍGUEZ, PEDRO A (2007): Contratos estatales, Bogotá, Editorial Temis.

51.LE PERA, SERGIO (1984): Joint venture y sociedad, Buenos Aires, Editorial Astrea.

52. LÓPEZ BLANCO, HERNAN FABIO (2013): Proceso arbitral, Bogotá, Editorial Dupré.

53.LÓPEZ GUZMÁN, FABIÁN (2002): Contratos internacionales de transferencia de tecnología. El know how, Bogotá, Ediciones Jurídicas Gustavo Ibáñez.

54.LÓPEZ GUZMÁN, FABIÁN (2007): Introducción al Derecho Mercantil Bogotá, Editorial Temis.

55. LÓPEZ GUZMÁN, FABIÁN (2008): El contrato de franquicia internacional, Bogotá, Editorial Temis.

56. LÓPEZ GUZMÁN, FABIÁN (2012): La sociedad por acciones simplificada SAS. Un modelo estratégico empresarial, Bogotá, Ediciones Doctrina y Ley. 
57. LÓPEZ GUZMÁN, FABIÁN (2004): Preguntas y respuestas de derecho comercial general, Bogotá, Ediciones Doctrina y Ley.

58. LÓPEZ GUZMÁN, FABIÁN (2003): Principios constitucionales de derecho comercial, Bogotá, Ediciones Doctrina y Ley.

59. MANGAS MARTÍN, ARACELI y LIÑÁN NOGUERAS, DIEGO J (1999): Instituciones y Derecho de la Unión Europea, Madrid,McGraw-Hill.

60. MARTÍNEZ NEIRA, NÉSTOR HUMBERTO (2014): Cátedra de derecho contractual societario. Regulación comercial y bursátil de los contratos societarios, Bogotá, Editorial Legis.

61. MARZORATI, OSVALDO J (1996): Alianzas estratégicas y joint ventures, Buenos Aires, Editorial Astrea.

62. MARZORATI, OSVALDO J (2003): Derecho de los negocios internacionales, 2 tomos, Buenos Aires, Editorial Astrea.

63. METKE MÉNDEZ, RICARDO (2001): Lecciones de propiedad industrial, Medellín, Editorial Diké.

64. MIQUEL RODRÍGUEZ, JORGE (1998): La sociedad conjunta (joint venture corporation), Madrid, Editorial Civitas.

65. MONROY CABRA, MARCO GERARDO (1999): Tratado de derecho internacional privado, Bogotá, Editorial Temis. 
66. MORALES ALZATE, JOHN JAIRO (2014): Consulta previa. Un derecho fundamental, Bogotá, Ediciones Doctrina y Ley.

67. NARVÁEZ GARCÍA, JOSÉ IGNACIO (1990): Obligaciones y contratos mercantiles, Bogotá, Editorial Temis.

68. NARVÁEZ GARCÍA, JOSÉ IGNACIO (1997): Teoría general de las sociedades, Bogotá, Legis Ediciones.

69. OHMAE, KENICHI (2005): El próximo escenario global. Desafíos y oportunidades en un mundo sin fronteras, Bogotá, Grupo Editorial Norma.

70. OSORIO MORENO, NÉSTOR DAVID(2008): Autonomía de la voluntad y joint venture en la Contratación Estatal, Bogotá, Grupo Editorial Ibáñez.

71.PACHÓN, MANUEL y SÁNCHEZ ÁVILA, ZORAIDA (1995): El régimen andino de la propiedad industrial, Bogotá, Ediciones Jurídicas Gustavo lbáñez.

72. PARRA, CARMEN (2002): El nuevo derecho internacional de los contratos, Bogotá, Universidad Externado de Colombia.

73.PARRA PARRA, JOSÉ EURÍPIDES (2004): El contrato de joint venture,Bogotá, Ediciones Jurídicas Gustavo Ibáñez.

74.PARRA PARRA, JOSÉ EURÍPIDES (2005): Sociedades extranjeras y negocios internacionales, Bogotá, Ediciones Jurídicas Gustavo Ibáñez.

75.PAULEAU, CHRISTINE (2003): El régimen jurídico de las joint ventures, Valencia, Editorial Tirant lo Blanch. 
76. PAULEAU, CHRISTINE (2005): Incidencia del derecho en la creación y el funcionamiento de las joint ventures,Barcelona-España,

77.PEÑA NOSSA, LISANDRO (2014): De los contratos mercantiles nacionales e internacionales, Bogotá, Ecoe Ediciones.

78. PEÑA NOSSA, LISANDRO (2014): De las sociedades comerciales, Bogotá, Ecoe Ediciones.

79. PORTER, MICHAEL (2006): Estrategia y ventaja competitiva, Barcelona, Ediciones Deusto.

80. RAVASSA MORENO, GERARDO JOSÉ (2004): Derecho mercantil internacional, Bogotá, Ediciones Doctrina y Ley.

81. RAVASSA MORENO, GERARDO JOSÉ (2001): Derecho mercantil. Bienes mercantiles, T. I, Bogotá, Ediciones Jurídicas Gustavo Ibáñez.

82. RAVASSA MORENO, GERARDO JOSÉ (2005): Títulos valores nacionales e internacionales, Bogotá, Ediciones Doctrina y Ley.

83. REMIRO BROTÓNS, ANTONIO (1999): Derecho internacional, Madrid, MacGraw-Hill.

84. REYES VILLAMIZAR, FRANCISCO (2006): Derecho societario, 2 tomos, Bogotá, Editorial Temis.

85. REYES VILLAMIZAR, FRANCISCO (2006): Derecho societario en Estados Unidos, Bogotá, Editorial Legis. 
86. RICHARD, EFRAÍN HUGO y MUIO, ORLANDO MANUEL (2004): Derecho societario. Sociedades comerciales, civil y cooperativa, Buenos Aires, Editorial Astrea.

87. ROA REYES, NELSON (2012):Derecho Comercial Curso Básico Actualizado, Bogotá, Librería Ediciones el Profesional Especializado.

88. RODNER, JAMES-OTIS (1993): La inversión internacional. En países en desarrollo, Caracas, Editorial Arte.

89. RODRÍGUEZ AZUERO, SERGIO (2005): Negocios fiduciarios. Su significación en América Latina, Bogotá, Legis Ediciones.

90. RODRÍGUEZ RODRIGO, JULIANA (2004): Joint venture internacional, en AA.VV., Estudios de contratación internacional, Bogotá, Pontificia Universidad Javeriana.

91.SALLENAVE, JEAN-PAUL (2002): La gerencia integral, Bogotá, Grupo Editorial Norma.

92. SAMUELSON, PAUL A., NORDHAUS, WILLIAM D (1996): Economía, Madrid, MacGraw-Hill.

93. SANTOS, BOAVENTURA DE SOUSA (1999): La globalización del derecho, Bogotá, Universidad Nacional de Colombia.

94. SIERRALTA RÍOS, ANÍBAL (1996): Joint venture internacional, Buenos Aires, Editorial Depalma. 
95.SIERRALTA RÍOS, ANÍBAL (2007): Negociación y contratación internacional. Teoría y casos, Bogotá, Editorial Legis.

96. SIERRALTA RíOS, ANíBAL y BAPTISTA, LUIZ OLAVO (1998): Aspectos jurídicos del comercio internacional, Bogotá, Editorial Temis.

97.STIGLITZ, JOSEPH (2002): El malestar en la globalización, Madrid, Editorial Taurus.

98.STUMPF, HERBERT (1984): El contrato de know how, Bogotá, Editorial Temis.

99.SUÁREZ BELTRÁN, GONZALO (2014): Estudios de derecho contractual público, Bogot', Editorial Legis.

100. SUÁREZ CAMACHO, GUSTAVO y JARAMILLO CARO, SANTIAGO (2002): Los contratos de asociación a riesgo compartido en telecomunicaciones, en la Revista de Derecho Público, num. 14, Bogotá, Universidad de los Andes, junio de 2002.

101. VELÁSQUEZ C, FRANSISCO JAVIER (2007): EI contrato de joint venture, Santiago de Chile, Editorial Jurídica Conosur Ltda.

102. VELILLA MORENO, MARCO ANTONIO (2001): Introducción al derecho de los negocios, Bogotá, Ediciones Jurídicas Gustavo Ibáñez.

103. ZAPATA DE ARBELÁEZ, ADRIANA; BARONA VILAR, SILVIA y ESPLUGUES MOTA, CARLOS (Dirs.) (2010): El arbitraje interno e 
internacional en Latinoamérica. Regulación presente y tendencias del futuro, Bogotá, Universidad Externado de Colombia. 